\title{
Flexicurity - a European Approach to Labour Market Policy
}

Although linguistically somewhat strange, "flexicurity", the combination of labour market flexibility and security for employees, has become a much praised cornerstone of European labour market policies. Obviously, in an environment with rapid technical progress and frequently changing market conditions, employers need to manage their labour force flexibly. In order to achieve this flexibility without creating an unbearable situation for employees, security is the second pillar of the concept. Security refers, however, to "employability" rather than safety from dismissal. As such, the concept looks like an innovative European way of consolidating economic and social interests, although some argue that much flexibility is gained while the security aspect is being neglected. The concept has been successfully adopted in some European countries, notably Denmark and the Netherlands. However, each country has to find its own concept of "flexicurity" using a distinct combination of instruments that fit the national institutional, social and civic context.

\section{Europe's Pathways to Flexicurity: Lessons Presented from and to the Netherlands}

$\mathrm{O}$ ne of the main challenges the European Union is currently facing is how, in the era of globalisation and ageing, to live up to European citizens' expectation of providing a distinct European Social Model. Can a true alternative be offered to sheer flexibilisation, deregulation and the degradation of social standards and social cohesion? Will a strong social Europe also be a strong economic Europe? Can Europe indeed follow its own path compared to the rest of the world? ${ }^{1}$

At the European level, the desire is expressed to maintain a solid balance between social and economic goals. The vexed question is how this model should be further developed in a concrete manner. As of 2006 this challenging question has specifically been dealt with under the heading of "flexicurity". The objective of flexicurity strategies is to combine employment and income security with flexibility in labour markets, work organisation and labour relations. This approach should transcend the simple trade-off between flexibility and security, where the former is seen to be in the exclusive interest of the employer and the latter in the interest of the employee. In a flexicurity strategy,

\footnotetext{
* Researcher, Tilburg University, The Netherlands.

** Professor, Tilburg University, The Netherlands.
}

flexibility and security should not be seen as opposites, but as mutually supportive labour market components.

Although initiated and formulated at the European level, for several reasons the flexicurity approach has to be developed into concrete policies and regulations at the member state level. First, viewing the wide differences in country practices and challenges, the EU rightfully does not believe in a one-size-fits-all approach. Second, it has to respect the autonomy of each member state regarding labour market and social policies. The EU has therefore recently proposed a set of flexicurity pathways, addressing different challenges and possible solutions in member states. In this article we firstly briefly review the EU perspective on combining social and economic goals. Secondly we show how the concept of flexicurity pathways responds to the necessity of combining these goals in different ways. Thirdly we take the Netherlands as a concrete national illustration of how lessons can be learned and presented from the flexicurity pathways

\footnotetext{
${ }^{1}$ See O. Blanchard: Is there a viable European social and economic model? Tilburg 2006, Tilburg University VanLanschot Lecture, 1 June 2006; A. Gid d en s: Europe in the Global Age, Cambridge 2007. Polity Press.
} 
methodology. We would like to stress also that in practice a country can seek inspiration from more than one ideal typical pathway.

\section{European Perspective on Economic and Social Goals}

The EU has tried to deal with economic and social goals in several ways since the first moments of its existence following the Treaty of Rome in 1957. Goetschy distinguishes three stages in the history of social Europe, reflecting different roles and interdependencies of the economy and social Europe. ${ }^{2}$ In the first decades of the existence of the EU she sees an emphasis on economic policies focusing on market integration, labour mobility and fair competition, to which social policy was subordinate. Social progress was marginal and often served economic goals.

In the second stage, starting with the Maastricht Treaty of 1992, this view changed slightly, leading to more leeway for social measures. However, social measures were still regarded as a means of increasing the acceptance of an accelerated economic integration. The Maastricht Treaty offered stimuli for the further development of both the micro- and macroeconomic dimension and of social dimensions. EU collective bargaining was made possible for instance, and the outcome of such bargaining could actually lead to framework agreements. In spite of initial enthusiasm, however, the options did not lead to impressive progress in the social dimensions.

The third stage was introduced by the Amsterdam Treaty of 1997, in which the Employment Title was incorporated. It introduced the possibility of setting European employment goals and monitoring the progress of member states. This system was implemented soon after the conclusion of the Employment Title in the form of the European Employment Strategy (EES). The EES, consisting of employment guidelines and goals, has its specific coordination mechanism, the Open Method of Coordination (OMC). Via the OMC European-wide goals can be set, while allowing for a diversified implementation across member states. The extension to both social and economic agendas and more policy coordination in these areas meant more integration of social and economic goals. This integration was further underlined by the integration of the employment guidelines with the micro- and macroeconomic guidelines in 2005. Such an integration can be comprehended in two ways: as a return to market logic or as the creation of an agenda for employment

\footnotetext{
2 J. Goetschy: The implications of the Lisbon Strategy for the future of social Europe: 'on the road' or 'new age'? in: The International Journal of Comparative Labour Law and Industrial Relations, Vol. 23 , No. 4 , pp. 499-523.
}

Intereconomics, March/April 2008 and social policies, putting them more or less on an equal footing with economic policies. ${ }^{3}$

The term flexicurity, that has been prevalent in the European debate as of 2006, has further developed an integrative outlook on social and economic issues by seeking ways to reconcile flexibility and security in the labour market. Can such an integrative view mark the fourth stage in the history of social Europe, putting social and economic goals on an equal footing? The core of the flexicurity idea is that security is a precondition for flexibility, and flexibility a precondition for security. It focuses on measures that offer sufficient flexibility on the labour market while at the same time offering sufficient security, regardless of whether this flexibility or security is demanded by employees or by employers. Much depends on if and how member states take up the flexicurity ideas and on the content of the policies and regulations they implement.

The OMC system that underlies the EES offers a great deal of leeway for member states to determine the necessity of balancing flexibility and security in their labour markets, and the concrete measures on how to obtain these goals. As such the EES also deals with the tension between the EU and the member states. By creating flexicurity policies within the framework of the EES, the EU can set European-wide goals, while giving member states the flexibility to deal with labour market issues in a way that fits their specific needs. The idea of a diversified approach at member state level is also present in the four flexicurity pathways that have been constructed by the European Commission building on the report by the European Expert Group on Flexicurity. ${ }^{4}$ These pathways will be explained below.

\section{European Flexicurity Pathways}

The concept of flexicurity pathways suggests different roads countries can take to improve their labour markets, based on different challenges, priorities and possibilities. The idea of pathways signals that the EU is aware that different countries face different challenges. This variety and diversity of welfare states across Europe is documented by many studies. ${ }^{5}$ The variety is linked to historical choices leading to subsequent economic and social institutions. In a path-dependent process, "history matters": it has a far-reaching impact, partly due to the cultural and value systems that underlie historical choices. Although a certain EU-led convergence of national policies can be recognised,

\footnotetext{
3 Ibid.

4 European Expert Group on Flexicurity T. Wilth ag en et al.: Flexicurity Pathways: Turning Hurdles into Stepping-Stones, Brussels 2007, Expert Report to the European Commission, June 2007.
} 
different modalities of flexicurity or combinations of flexibility and security can be ${ }^{5}$ observed. ${ }^{6}$ To some extent, these modalities of flexicurity can be considered functional equivalents that are compatible with diversity in the national styles of regulation or regimes that have emerged over the years. ${ }^{7}$ Thus, resulting from consultations and negotiations at national level, flexicurity can take different forms from country to country. Member states should assess their own situation and identify their own meaningful flexicurity pathways to cope with different labour market challenges.

The flexicurity policies can be designed and implemented across four policy components defined by the Commission, which may be mutually supportive. In our own words these four components are:

- flexible and secure contractual arrangements

- efficient active labour market policies (ALMP) to strengthen transition security

- systematic and responsive life-long learning

- modern social security provisions that also contribute to good mobility in the labour market.

Moreover, we add a fifth component to this list, as a general precondition or process variable, i.e. the development of a supportive and productive social dialogue. ${ }^{8}$ For a complete overview of all the policy suggestions of each step belonging to each ideal typical pathway, we refer to the report of the Flexicurity Expert Group.

\section{Flexicurity Pathway 1: Dealing with Flexibility at the Margin}

The first pathway addresses the issue of flexibility at the margin of the labour market. It suggests reducing asymmetries between standard and non-standard

5 See P. Hall, D. Soskice (eds): Varieties of Capitalism: The Institutional Foundations of Comparative Advantage, Oxford 2001 Oxford University Press, Introduction, p. 1; R. Whitley: Divergent Capitalisms, Oxford 2000, Oxford University Press. For further references see: W. Arts, J. Gelissen: Three worlds of welfare capitalism or more? A state-of-the-art report, in: Journal of European Socia Policy, Vol. 12, No. 2., 2002, pp.137-158; G. Esping-Andersen: The Three Worlds of Welfare Capitalism, Princeton 1990, Princeton University Press; G. Esping-Andersen: The Social Foundations of Post-industrial Economies, Oxford 1999, Oxford University Press A. Sapir: Globalisation and the Reform of European Social Models, Brussels 2005, Bruegel Policy Brief, 2005, No.1;

${ }^{6}$ K. Philips, R. Eamets: Approaches to flexicurity: EU models, Luxembourg 2007, European Foundation for the Improvement of Living and Working Conditions; European Commission: Employment in Europe 2006 and European Employment 2007.

7 The relevance of the flexicurity concept for various parts of the EU is underlined by a recent book publication from the ILO: S. C azes, A. $\mathrm{Nesporova:} \mathrm{Flexicurity.} \mathrm{A} \mathrm{relevant} \mathrm{approach} \mathrm{in} \mathrm{Central} \mathrm{and} \mathrm{Eastern}$ Europe, Geneva 2007, International Labour Office.

8 The European Social partners also put this as a fifth element in their report Key challenges facing European labour markets: a joint analysis of European Social Partners, Brussels, October 2007. work by promoting upward transitions in the labour market and by integrating non-standard contracts fully into labour law, collective agreements, social security and life-long learning systems. Alternatively, standard contracts could be made more attractive to companies by introducing an open-ended contract in which specific elements of protection are built up progressively with time, until "full" protection is achieved. Such a contract guarantees basic but adequate protection from the start and automatically builds up "full" protection as the working relationship continues. Social partners and governments should negotiate the terms of these arrangements.

Within this pathway the first flexicurity component can particularly attend to the asymmetries between standard and non-standard contracts. Non-standard contracts are then treated as equal to standard contracts, following the principle of pro rata temporis. In the next part of this paper we turn to the example of the Netherlands in order to illustrate how this step was fairly successfully taken in the Dutch context.

\section{Flexicurity Pathway 2: Securing Transitions from Job to Job}

The second pathway emphasises safe and successful job-to-job transitions. Built-in contractual guarantees and human resource management policies should ensure timely progress into new jobs either within the company or outside the company once the necessity arises. Furthermore, it may be feasible to introduce individualised transition guarantees to redundant workers, to be borne jointly by employers, social partners and public employment services in order to prevent unemployment. A strong system of life-long learning and vocational training may form the basis for productive labour market transitions both inside and outside companies. Such a system should allow for quick access to effective training funds and facilities at branch level. Within this pathway, strengthening internal flexicurity is also relevant, especially to enhance the employability and skills of workers.

In the Dutch example, as we will see, transition security can be improved, turning it into a generalised principle within the labour market not limited to large firms that can afford outplacement and retraining.

Flexicurity Pathway 3:

\section{Access to Learning and Good Transitions for All}

This pathway recommends strengthening, on the basis of existing levels of labour market dynamism, investment in skills and R\&D. The employment and security opportunities and options of specific groups in the labour market can thereby be enhanced and productivity growth boosted. A broad-ranging approach Intereconomics, March/April 2008 
is needed to keep the labour market accessible to the low-skilled and other groups at risk, such as minorities, older workers, women and the early school leavers, and to prevent them from becoming long-term unemployed or excluded in other ways. Flexicurity will benefit from the possibility of concluding binding agreements at branch or regional level that combine provisions on how to address the flexibility needs of both employers and workers by investment in training. Where the institutional structures for such agreements are not yet in place, support from the social partners and government is needed.

In the case of the Netherlands this pathway is also relevant as the Dutch labour market can be portrayed as a fairly inclusive labour market where nonetheless specific groups, as identified above, are still facing skills and opportunity gaps. We will elaborate this below.

\section{Flexicurity Pathway 4: \\ Comprehensive Social Security Supporting Transitions to Regular Work}

This pathway starts from the urgent need to increase the employment and job opportunities of persons who are currently on social security benefits or working in the informal sector. Active labour market programmes and social security should offer sufficient opportunities and incentives, in terms of increased conditionality of benefits, to return to work and to facilitate this transition. Long-term welfare dependence could thus be prevented. Informal work can be regularised by offering flexi-secure contracts, lower payroll taxes and a skills perspective for these sectors. By formalising informal economic activities, increased financial resources can be raised for building up a more comprehensive social security system. Stronger institutional capacity needs to be developed by stimulating the social partners to negotiate key elements of working conditions and by better cooperation between labour market and social security institutions. Social dialogue can be further developed at sector and regional level and both, bipartite and tripartite dialogue can be strengthened.

\section{Flexicurity Practices in the Netherlands}

At the national level, in the member states, various labour market initiatives and reforms have taken place over the past decade which could qualify as flexicurity strategies; i.e. they have taken an integrative view of flexibility and security. ${ }^{9}$ The Netherlands serves as an

\footnotetext{
9 Many more examples of flexicurity practices in the 27 Member States can be found in the report of the Rapporteur of the European Expert Group on Flexicurity, entitled Flexicurity Pathways (June 2007), http://ec.europa.eu/employment_social/employment_strategy/pdf/ flexi_pathways_en.pdf
}

Intereconomics, March/April 2008 example here. Together with Denmark the Netherlands are often referred to as flexicurity examples. ${ }^{10}$ Dutch flexicurity policies have been developed rather deliberately and can be described as the normalisation of atypical work while preserving flexibility in the labour market. This approach, combined with the relatively good labour market results in recent years, has served as an example at the European level in the early stage of the flexicurity policy-making process. In 2007 the Netherlands had an employment rate of $74.3 \%$ and an unemployment rate of $3.2 \%$, compared to $64.5 \%$ and $7.1 \%$ respectively in the $27 \mathrm{EU}$ member states (EU27). ${ }^{11}$ In recent years economic growth has been modest to good $-2.3 \%$ is expected for 2008 - and inflation is rather low at $2.0 \%$ compared to the EU average of $3.2 \%$.

Contractual diversity, including part-time work, fixed-term work and agency work, is rather high in the Netherlands. In $200646 \%$ of the employed labour force worked part-time (18\% in EU27). Working parttime is even regarded as a normal and desired type of employment, illustrated by the high amount of parttime workers who report that they voluntarily work in this type of employment. Especially women work parttime (75\% in NL compared to $31 \%$ in EU27 in 2006). Moreover, the percentage of employees with a contract of limited duration was $16.6 \%$ in 2006 (14.4\% in EU27).

Security for these "atypical" workers is provided in several ways, notably by strictly applying, by law, the pro rata temporis principle to part-time workers. ${ }^{12}$ This holds true not only for the position of the employee under civil law, but also for social security legislation and entitlements. Two laws in particular are relevant to part-time workers, but also to fixed-term workers: the Prohibition of Discrimination by Working Hours Act (Wet Verbod onderscheid arbeidsduur, WVOA) and the Adjustment of Working Hours Act (Wet Aanpassing Arbeidsduur, WAA). The WVOA came into effect on 1 November 1996. One of the consequences of its introduction was the addition of Article 7:648 to the Dutch Civil Code. This Article forbids employers to discriminate between employees on the basis of a difference in working hours in the conditions under which

\footnotetext{
10 See e.g. European Commission: Employment in Europe 2006, Luxembourg 2006.

11 All figures presented in this section are based on Eurostat calculations.

12 See more comprehensively J. Visser, T. Wilthagen, R. Beltzer and E. Koot-van der Putte: The Netherlands: from atypicality to typicality, in: S. Sciarra, P. Davies, M. Freedland (eds.): Employment Policy and the Regulation of Part-time Work in the European Union. A Comparative Analysis, Cambridge 2004, Cambridge University Press, pp. 19-223.
} 
those employees enter, extend or terminate a contract of employment, unless there is objective justification for such discrimination. Clauses that conflict with this ban are void. If the employer terminates the contract in contravention of the ban, or terminates it because the employee has invoked this ban, the termination is subject to annulment. The same ban also applies to government employers, now that a stipulation to the same effect has been incorporated into Article $125 \mathrm{~g}$ of the Central and Local Government Personnel Act. The WAA came into force on 1 June 2000. This Act was the result of nearly nine years of political negotiation. It represents a very high-profile piece of legislation as it lends employees the right, albeit under certain conditions, to unilaterally alter the terms of an already existing employment contract.

With regard to agency workers, on-call workers and the like, a new approach to labour market flexibility and (in)security was adopted at the end of 1995 when the Dutch Minister of Social Affairs and Employment deliberately attempted, in a memorandum called "Flexibility and Security", to strike a balance between flexibility and (social) security. ${ }^{13}$ This memorandum contains an interrelated set of starting-points and proposals for modifying the dismissal protection enjoyed by employees in standard employment relationships, abolishing the permit system for temporary work agencies in respect of their placement activities and enhancing the legal position of temporary agency workers, whose relationship with the agency is to be considered, in principle, a standard employment contract.

In the Dutch coalition government (a coalition of Labour, Liberals and Social Liberals) at that time, no agreement on the flexibility and security proposals could be reached. Subsequently, the Foundation of Labour was asked for its advice on this matter. The Foundation of Labour is a consultation and advisory body at the central level, which was established at the end of the Second World War. Its members constitute the largest confederations of employers' and workers' organisations. Unlike the Socio-Economic Council, the Foundation of Labour has no members or representatives from the government. The Foundation of Labour is central to the Dutch "consultation" economy, or the "Polder Model", as it is called nowadays.

13 See also T. Wilthagen, F. Tros: The concept of 'flexicurity': a new approach to regulating employment and labour markets, in: Transfer, Vol. 10, No. 2, 2004, pp. 166-186; and T. Wilthagen, Mijke Houwerzijl: How does flexibility affect social cohesion? The Council of Europe's tree model revisited, in: Council of Europe: Reconciling labour flexibility with social cohesion - Facing the Challenge, Strasbourg 2005, Council of Europe (Trends in social cohesion, No. 15), pp. 109-131.
It is an institution that is remarkable for its strategies of positive sum bargaining. The pursuit of "win-win" strategies and results, as perceived from the point of view of both workers and employers, is at the core of the Foundation.

Under the umbrella of the Foundation employees' and employers' confederations managed to draft a detailed agreement on flexibility and security on 3 April 1996. Moreover, at the same time the employers' organisations, the trade unions and the non-profitmaking employment agency START had reached an agreement on regulating the legal position of temporary agency workers after the new laws came into force. They had decided on a collective agreement that was to run for five years. On 7 March 1997, the Flexibility and Security Bill was submitted to the lower house of the Dutch parliament, together with the Allocation of Workers via Intermediaries Bill, which provided for the abrogation of permits for temporary work agencies. Without much further debate the new legislation came into force on 1 January 1999.

The new law abolished the permit system for operating temp agencies. More rights were attributed to flexible workforces, and slightly fewer rights to coreworkers. On the other hand more leeway was created for (prolonging) fixed-term contracts. A key role was, and is, played by the collective labour agreements in the temp agency sector which were concluded for the periods of 1999-2003 and 2004-2009 respectively. Temp agency workers have, depending on tenure, a right to fixed-term or permanent contract with the agency, training (individual budget) and pension. After 26 weeks (or earlier) of working for the same company they are entitled to the same wage as the employees of that company. The hiring company saves on hiring and firing costs, but pays more for temp workers than for their own employees (as the costs for the agency are put on top of the wage costs of the agency worker). For now it is important that this example of a flexicurity policy clearly contains an explicit and well-considered trade-off between forms of flexibilisation, i.e. enhanced external numerical flexibilisation and forms of security for weak groups, more employment and employability security for temporary agency workers and other non-standard workers such as on-call workers. Furthermore, it is safe to argue that this reform could never have been launched and implemented if it were not for the joint efforts of the social partners, at both the central and the sector level.

Notwithstanding these developments the Netherlands - and the same applies to Denmark - should not be regarded a flexicurity paradise or utopia. Like

Intereconomics, March/April 2008 
any country, the Netherlands faces various employment challenges and should map out its own pathway with the necessary steps for improvement. Inspiration could be sought notably from flexicurity pathways 2 and 3 .

First, regulations and policies can be improved in order to strengthen the position of specific groups in the labour market, in particular that of ethnic minorities that have a hard time entering into and progressing in the labour market. Although unemployment among non-western non-nationals decreased significantly in 2007 , the unemployment rate of $9.1 \%$ is still almost three times higher than the unemployment rate among Dutch nationals. ${ }^{14}$ In the age group 15-25 years the unemployment rate amounts to $15 \%$ for non-western non-nationals and $8.1 \%$ for nationals. Early schoolleaving is a problem, particularly among non-nationals. Likewise the unemployment rate of people with a low level of education is considerably higher than the Dutch average.

Older workers form another vulnerable group. A large number of these workers have insufficient transition and employment security, i.e. they lack the security to make a timely transition to another job when the need arises, e.g. in cases of restructuring. Some aspects of the Dutch system of dismissal protection, which is fairly strict for insiders and more relaxed for outsiders in the labour market, contribute to this status quo within companies and this is currently causing a heated debate. Moreover, Dutch companies lag behind in investing in the skills and retraining of their older workers compared to young workers. Whereas half of the Dutch employees in the age categories 16-24 and 25-34 years took part in education or training for their job or profession in 2004-2006, only 30\% of the workers aged 55-64 could say the same. ${ }^{15}$ Also, reintegration back into the labour market in the case of unemployment or disability is disproportionally hard for older workers. This calls for the development of a general and effective system of transition and employment security, not limited to large firms that already operate mobility centres and the like. Collective agreements, wage sum reservations and the broadening of the existing Dutch Life Course Saving Arrangement could be vehicles for this reform.

\footnotetext{
14 Data from Statistics Netherlands, using the national definition of unemployment which differs from the international Eurostat definition. The main difference is that Statistics Netherlands only regards a person as unemployed if a person is actively looking for a job of at least 12 hours a week.

15 Data: Institute for Labour Studies (OSA), Tilburg, The Netherlands.
}

A third urgent concern in the Dutch context are of the career opportunities of women, including pay gaps and the lack of women in top management in companies and institutions. The fact that these career opportunities are related to the effects of working part-time, even where this is a highly desired form of employment. Another problem linked with the "Dutch model" arises form the fact that longer working hours are required to warrant the sustainability of the social security system in an aging society, also represent a true challenge to the Dutch flexicurity system.

This evaluation neatly matches the European Commission's recommendations to the Netherlands, among which are facilitating the transition from parttime to full-time work, reducing the gender pay-gap, reducing early school-leaving, and increasing overall labour supply. Partly similar suggestions have recently been forwarded by the OECD and the IMF.16

\section{Conclusions}

The attempts at the European level to productively combine and promote both social and economic goals could now reach the stage where words could be further converted into action. At least this is the idea underlying the flexicurity concept. At the end of the day, the aim of flexicurity policies should be to ensure the welfare and well-being of our societies and all their members, now and in the future. It can therefore be argued that flexicurity is ultimately about security and sustainability. At the same time the European ideas and principles on flexicurity first and foremost need to be seen as a framework which may offer inspiration and guidance to member states to review and improve their labour markets in terms of establishing a sound balance between flexibility and security. Member states can and should come up with their own tailor-made policies and regulations that are geared towards their specific history, starting-position and political, institutional and cultural context. This diversified approach is one of the ideas present in the concept of European flexicurity pathways that have been constructed at the EU level. The past attempts of the Netherlands to reconcile flexibility and security serve as one of the many European examples. However, like other European countries, the Netherlands can still find much inspiration in the pathways that have been formulated, to evaluate its labour market situation, to tackle current issues and to find adequate solutions, contributing to flexibility and security for all.

16 See e.g. IMF, Kingdom of the Netherlands: The Netherlands 2008 Article IV Consultation: Preliminary Conclusions, 17 March 2008. 


\section{Flexicurity in Danish - A Model for Labour Market Reform in Europe?}

l: the flexicurity literature, the Danish employment system is often referred to as a prime example of a labour market with a well-functioning flexicurity arrangement - even to such a degree that the "Danish model" and "flexicurity" are sometimes seen as almost identical. The Danish road to fame has been supported by a number of impressive statistics. Thus the Danish employment rate of 77.4 per cent (in 2006) is the highest among the 27 members of the European Union. The rate of unemployment was 3.9 per cent in 2006 and is expected to decline further to about 3 per cent in 2007 and the following years. The macroeconomic indicators are generally sound.

When discussing flexicurity in a Danish context, it should be remembered that flexicurity is much more than just a single national model. ${ }^{1}$ On the contrary, there are many ways of combining different forms of flexible working arrangements with different forms of security. However, the specific interplay between the welfare state and the labour market in Denmark can be interpreted as a remarkable "hybrid" between the flexible, free-market welfare states characterised by high numerical flexibility (liberal hiring-and-firing rules) and the generous Scandinavian welfare regimes of high social security (relatively high benefit levels). Therefore Denmark is an outstanding case regularly mentioned in the literature. ${ }^{2}$

The Danish labour market model is often depicted as a "golden triangle" of flexicurity, cf. Figure 1. The model combines high mobility between jobs with a comprehensive social safety net for the unemployed and an active labour market policy. Measured on a year-to-year basis, every year about 25 per cent of all employees are newcomers to their specific employer. About two thirds of the newly hired come from another job, while the remainder come from unemployment or are new entrants to the labour market. ${ }^{3}$ In fact mobility (measured by job mobility, job creation, job destruction and average tenure) is remarkably high in an international comparison. ${ }^{4}$ The high degree of worker mobility between jobs is definitely linked to the rela-

* Professor and Director of the Centre for Labour Market Research (CARMA), which is affiliated with the Department of Economics, Politics and Public Administration, University of Aalborg, Denmark. tively modest level of job protection in the Danish labour market. Another reason could also be higher risk willingness among workers due to the comprehensive social safety net and probably also the low stigmatising effects of social security in Denmark.

Despite having one of the lowest levels of job protection among OECD countries ${ }^{5}$, Danish workers have a feeling of high job security among all subgroups of workers. ${ }^{6}$ Also, a recent Eurobarometer reported that a majority of more than 70 per cent of the Danes found it a good thing to change jobs every few years. This can be contrasted with a level of below 30 per cent in countries like Austria, Germany and Poland. ${ }^{7}$

The arrows between the corners of the triangle in Figure 1 illustrate flows of people. Even if the unemployment rate is low in an international perspective, Denmark almost has a European record in the percentage of employed which are affected each year by

1 T. Wilthagen, F. Tros: The concept of 'flexicurity': A new approach to regulating employment and labour markets, in: Transfer, European Review of Labour and Research, Vol. 10, No. 2, 2004, pp. 166-187.

2 For more detailed expositions of the Danish employment system and the lessons that can be learned from it, reference can be made to Madsen and to Bredgaard et al.: P. K. Madsen: How can it possibly fly? The paradox of a dynamic labour market in a Scandinavian welfare state, in: John A. Campbell, John A. Hall, Ove K. Pedersen (eds.): National Identity and the varieties of Capitalism: The Danish Experience, Montreal 2006, McGill-Queen's University Press, pp. 321-355; P. K. Madsen: Distribution of Responsibility for Social Security and Labour Market Policy. Country Report: Denmark, AIAS working paper 2007-51, Amsterdam 2007, Amsterdam Institute for Advanced Labour Studies, University of Amsterdam; T. B re dga a rd, F. Larsen, P. K. Madsen: The flexible Danish Labour Market - A Review, CARMA Research Papers 1:2005, Aalborg University, CARMA; T. Bredgaard, F. Larsen, P. K. Madsen: Opportunities and challenges for flexicurity - the Danish example, in: Transfer, European Review of Labour and Research, Vol. 12, No. 1, 2006, pp. 61-68; T. Bredgaard, F. Larsen, P. K. Madsen: The challenges of identifying flexicurity in action - A case study on Denmark, in: H. Jørgens en, P. K. Mads en (eds.): Flexicurity and beyond: finding a new agenda for the European social model, Copenhagen 2007, DJøF Publishing, pp. 365-391.

3 T. Bredgaard et al.: The challenges of identifying ..., op. cit.

4 P. K. Madsen: How can it possibly fly? ..., op. cit.

5 OECD: Employment Outlook, Paris 2004, chapter 2.

6 P. Auer, S. Cazes: Employment stability in an age of flexibility. Evidence from industrialized countries, Geneva 2003, International Labour Organization.

7 Eurobarometer: Survey on Europeans and Mobility, Luxembourg 2006, p.6.

Intereconomics, March/April 2008 
Figure 1

\section{The Danish "Flexicurity Model"}

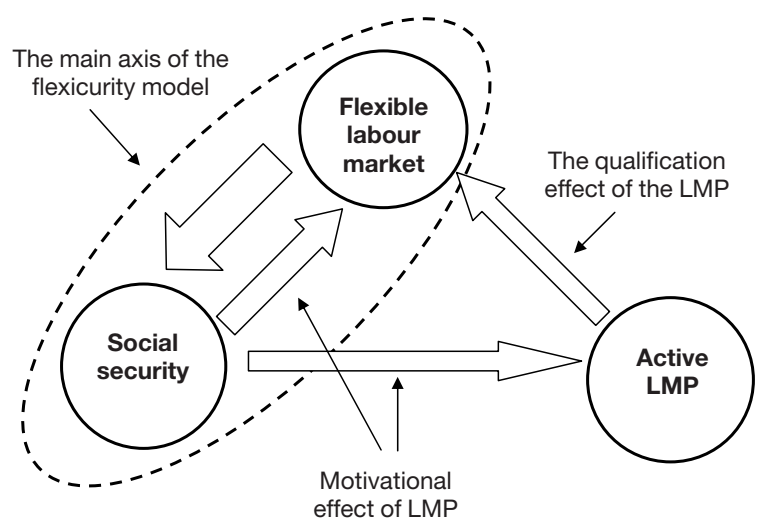

Source: P. K. Madsen: How can it possibly fly? The paradox of a dynamic labour market in a Scandinavian welfare state, in: John A. Campbell, John A. Hall, Ove K. Pedersen (eds.): National Identity and the varieties of Capitalism: The Danish Experience, Montrea 2006, McGill-Queen's University Press, pp. 321-355.

unemployment and receive unemployment benefits or social assistance (around 20 per cent). However, the majority of these unemployed persons manage to find their own way back into a new job. Those who do not rapidly find a job by themselves constitute the target group for the active labour market policy (ALMP), which - ideally - helps them to find employment again.

By international comparison, Danish ALMP must be characterised as both expensive and ambitious. When it comes to spending, the costs of ALMP amounted to 1.7 per cent of GDP in 2005, which is the highest level among the OECD countries. ${ }^{8} \mathrm{~A}$ further important feature of Danish labour market policy is the emphasis on early intervention in the sense that after one month of unemployment all unemployed enter a regime of mandatory activities such as interviews, counselling and monitoring of active job seeking. After six or nine months, depending on age, the unemployed must, furthermore, take part in some form of active measure (like job training or labour market education).

The model in Figure 1 illustrates two of the most important effects in this connection. On the one hand, as a result of the active measures, the skills of the participants in various programmes are upgraded. Therefore their chances of getting a job are improved. This is the "qualification effect" of ALMP.

On the other hand, the measures have a motivational (or threat) effect in that unemployed persons

$\overline{8}$ OECD: Employment Outlook, Paris 2007, p. 271. who are approaching the time when they are due for activation may intensify their search for ordinary jobs, if they consider activation a negative prospect. Thus one effect of labour market policy will be to influence the flow from unemployment benefits back to work, also for those unemployed who do not actually participate in the active measures. An econometric study has in fact concluded that this motivational effect accounts for the major part of the macro-effect of ALMP in Denmark. ${ }^{9}$

As an indication of the relative success of this ALMP regime, the incidence of long-term unemployment as a percentage of the labour force was 0.8 in 2006 compared to 3.1 in EU15 and 3.6 in EU27. ${ }^{10}$

Finally, it is important to note that the Danish "model of flexicurity" is not the result of a well-defined grand scheme, but the outcome of a long historical development with strong elements of path dependency.

Thus, the high level of worker mobility supported by a low level of employment protection is a long-standing feature of the Danish labour market dating back to the General Agreement between the social partners that was the outcome of a general strike in 1899. Similarly, when it comes to income security, the present version of the system for economic support for the unemployed dates back to the last large reform of the unemployment benefit system in 1970, when the state took over responsibility for financing the extra costs of unemployment benefits that were caused by increases in unemployment (the principle of public financing "at the margin").

The third element in the triangle, active labour market policy, is also the outcome of a long tradition of interventions into the functioning of the labour market. Labour market policy in Denmark has a long political legacy, although it only developed into a distinct policy area in the mid-1960s. Also, reforms of labour market policy in the 1990s were the outcome of a carefully prepared compromise which was struck in the early 1990s in a special tri-partite committee. Therefore corporatist structures play an important role in explaining the development and robustness of the particular Danish version of "flexicurity". ${ }^{11}$

In both the international and the Danish debate there has, from time to time, been a tendency to jump

\footnotetext{
9 M. Rosholm, M. Svarer: Estimating the Threat Effect of Active Labour Market Programmes, IZA Discussion Paper No. 1300, 2004.

10 European Commission: Employment in Europe 2007, Luxembourg, p. 30 .

11 H. Jørgensen: Consensus, cooperation and conflict - The policy-making process in Denmark, Cheltenham 2002, Edward Elgar.
} 
to the conclusion that the success of the last decade is a result of the flexicurity model just described. It is, however, essential to point out that the positive trend in the Danish labour market since the early 1990s is not attributable exclusively to the Danish flexicurity model. Without a successful balancing of macroeconomic policy and the trends in the international business cycle, the growth in employment and the falling unemployment would not have been possible.

The coinciding of low inflation and a halving of registered unemployment rates is also a by-product of a new agenda for collective bargaining and wage formation, which helped the labour market adjust to the shift from high unemployment to full employment while keeping wage increases at a moderate level and not departing from the international trend towards low inflation. This agenda developed gradually during the 1980s and was formalised by a joint declaration of the social partners in 1987, in which they stated that they would take the international competitiveness and macroeconomic balance of the Danish economy into account during wage negotiations.

Finally, it is important to stress two things. First of all, while the "flexicurity triangle" in Figure 1 points to some outstanding features of the Danish employment system, it still represents a sort of "ideal type". In reallife Denmark, flexibility is of course not only about hiring and firing. Danish firms also to a large extent apply other forms of flexibility, including functional flexibility and working time flexibility. By way of example, the collective agreements of recent years have permitted still longer periods over which the normal working week of 37 hours may be averaged, thus allowing employers to vary working time more freely, without having to pay for overtime.

Secondly, the Danish labour market is not immune from the problems which are faced by other European countries. Danish workers may also become marginalised from the labour market and end up in early retirement or long-term sickness. The employment situation of immigrants and descendants, in particular, is difficult. While unemployment is very low at present, the Danish version of flexicurity is no guarantee that it will not increase again due to falling demand as it has done in recent decades. The main indicator of the merits of the particular composition of the Danish employment system is therefore not the current low unemployment, but the fact that Denmark during the whole post-war period has been able to survive as a high-income small open economy in an ever more global environment. ${ }^{12}$

\section{The Transferability of the Danish Experience}

Given the political attractiveness of flexicurity as a strategy and the accomplishments of the countries in which flexicurity is found as a widespread state of the employment system, it is not surprising that there is a great interest in learning from the more successful neighbours. However, due to the complexity of many flexicurity arrangements and their specific historical, social and political backrounds, simple transfers of institutions or policies are rarely feasible.

The booming literature on policy transfer and Europeanisation illustrates the options for, but also the barriers to, policy learning either directly from the neighbours or from policies advocated by supranational bodies like the European Union. ${ }^{13}$ Inspired by Schmidt ${ }^{14}$ one can list a number of factors which determine the transferability of policies into a given country. These include its economic vulnerability exemplified by the presence or absence of economic crisis and the political institutional capacity, which is inherent in the principal policy actor's ability to impose or negotiate change. Important factors are also policy legacies and preferences, which determine the "fit" of potential policies with long-standing policies and institutions and with existing preferences. Related to the latter is also the flexibility or robustness of the national policy discourse, determining the ability to change preferences by altering perceptions of, for instance, economic vulnerabilities and policy legacies.

With direct reference to the transferability of flexicurity policies, Wilthagen ${ }^{15}$ has also stressed the importance of political institutional capacity in the form of mutual trust between the social partners and the government when it comes to developing flexicurity policies. Adequate central and de-central level platforms and channels for coordination, consultation and negotiation are also highly important.

12 J. L. Campbell, O. K. Pedersen: The Varieties of Capitalism and Hybrid Success: Denmark in the Global Economy, in: Comparative Political Studies, Vol. 40, 2007, pp. 307-332.

13 P. K. Madsen: Flexicurity - Towards a Set of Common Principles?, in: The International Journal of Comparative Labour Law and Industrial Relations, Vol. 23, No. 4, pp. 525-542.

14 Vivien Schmidt: Europeanization and the Mechanics of Economic Policy Adjustment, in: Journal of European Public Policy, Vol. 9, No. 6, 2002, pp. 894-912.

15 T. Wilthagen: Striking a Balance? Flexibility and Security in European Labour Markets, in: T. Bredgaard, F. Larsen (eds.): Employment policy from different angles, Copenhagen 2005 DJøF Publishing, pp. 253-267, here p. 265. 
The importance of these points is of course related to the core of the flexicurity concept: moving from one configuration of levels of flexibility and security to another will often involve one of the parties' (typically the employees) having to accept some form of increased flexibility (and thus uncertainty) in their working life in order to get compensation in the form of improved security arrangements provided by the employers or the state. For the employees this obviously implies the risk of being cheated by accepting more flexibility but never getting the reward in the form of increased security. Trust created by historical experiences with bargaining processes and maybe supported by some form of state guarantee is necessary.

Furthermore, one can point to the fact that the preexistence of a certain institutional infrastructure will facilitate specific flexicurity arrangements. A well-developed system of industrial relations with established patterns of negotiations between the social partners at different levels and also between the social partners and government will of course facilitate the sort of bargaining and compromising which is important in creating and sustaining flexicurity arrangements.

Also, institutions supported by the public sector can be important. For example, a comprehensive public system for adult education and training will make it easier to develop flexicurity arrangements, which involves employment security upgrading the skills of unemployed workers or workers in risk of unemployment. Also, a well-developed system of childcare is indispensable for creating security for working parents and thus for a flexible supply of, especially younger, women on the labour market.

However, the aim of this presentation is not to provide detailed prescriptions on how to implement flexicurity policies in specific national contexts. This is a complex task better left to national analysts and policymakers in the respective countries. Here, a better comprehension of best practices with respect to flexicurity policies from other countries, including Denmark, can act as an important source of inspiration and can lay the ground for shifts in national discourses, which over time may lead to a "subtle transformation of states". ${ }^{16}$ The main attraction of Denmark in this context is therefore its uniqueness as a European country which has implemented an encompassing version of a specific form of flexicurity. And as any teacher will know, one real-life example tells more than a torrent of abstractions.

\footnotetext{
16 K. Jacobsson: Soft regulation and the subtle transformation of states: the case of EU employment policy, in: Journal of European Social Policy, Vol. 14, No. 4, 2004, pp. 355-370.
}

\section{Conclusion - Learning from Denmark?}

The general message of this article is that the positive international attention lavished on Denmark in recent years is in fact justified. Measured on a number of different dimensions, the Danish labour market does indeed demonstrate a high degree of flexibility. Above all the extraordinary Danish combination of high mobility between jobs, low job security and high rates of unemployment benefit deserves attention, and makes it possible to interpret the Danish labour market model as a unique variety of flexicurity. On top of this comes a highly developed active labour market policy - and in general a well-developed (continuous) educational system - which add an element of employment security by strengthening the labour market competences of both the unemployed and people in employment.

When this unique flexicurity model is taken as a source of inspiration, it must be realised that it makes certain demands on the social partners and the political decision-makers. The trade unions must accept employment security rather than job security. That can be difficult, particularly in times of increasing employment insecurity due for instance to the off-shoring of jobs. The best response in this situation is not increased job protection but improved employment security for exposed or vulnerable groups, e.g. massive investments in adult vocational education and training.

For their part, the employers must come to terms with the fact that a precondition for the low degree of job protection not resulting in increasing employment insecurity is a well-functioning, generous and relatively expensive unemployment and social assistance system. Parallel to this, the political decision-makers must realise that substantial changes at any of the corners of the flexicurity triangle are impossible without serious repercussions for the other corners of the triangle. Any political intervention in the labour market must therefore be based on a holistic understanding.

These lessons to be learned - and mutually recognised - are vital to preserve a flexible and secure labour market. They also demonstrate how difficult it will be to export this model to other European countries. One transferable lesson, however, is that a generous welfare state is not incompatible with a dynamic and well-functioning labour market. This lesson extends beyond the correlation between a labour market characterised by low job protection, generous unemployment benefits and active labour market policy.

The high degree of flexibility on the Danish labour market is, furthermore, supported more indirectly by a number of welfare state services such as a compre- 
hensive educational system, including adult vocational training and education, a well-developed childcare system, (relatively) well-functioning and publicly financed health care etc. From a short-term perspective, the Danish model therefore seems to be very costly - a comment which is often made by foreign observers. However, from a labour market perspective, many of these welfare schemes can be viewed as investments in well-functioning structures, rather than costs. These structures support a dynamic on- going transformation of the whole economy, which allows for a high level of competitiveness and high employment - and creates the economic foundation for a sustainable welfare system.

Hopefully, these lessons about the competitive advantages of social dialogue and a comprehensive welfare state can serve as inspiration for the development of the social model in other countries in Europe or elsewhere.

Jianping Zhou*

\section{Denmark's Flexicurity Model: The Answer for Europe?}

$T^{\mathrm{n} m a n}$ he Danish flexicurity model has attracted attention among policymakers in Europe because it suggests that a flexible labour market can coexist with a generous welfare system to achieve low unemployment. Should and can the Danish model be adopted by other European countries to reduce unemployment? In this article, which is based on a published IMF working paper, ${ }^{1}$ I look into the key elements of the flexicurity model, analyse their effects on unemployment, and find that an answer is not obvious.

The Danish labour market model, the "flexicurity" model, has been widely praised recently for its association with a low unemployment rate and a high standard of social security for the unemployed. ${ }^{2}$ Within this model, a high degree of labour market flexibility coexists with a high level of social protection engendered by generous unemployment benefits and active labour market policies. At a time when most European countries are facing chronically high unemployment rates but the needed labour market reforms often face strong political opposition - for fear that they can significantly erode job and income security - the Danish flexicurity model seems to suggest that this fear is unfounded and that it is possible to reduce the unemployment rate with a model that balances flexibility with security. Thus, the flexicurity model looks increasingly attractive to policymakers in Europe. At recent European Commission summits on the Lisbon strategy, member states were invited to pursue reforms in labour market and social policies under an integrated flexicurity-type approach, although without concrete guidelines as to how this integrated approach should look.

* Economist, International Monetary Fund, Washington.
The relationship between the Danish flexicurity model and its unemployment performance, however, is not as straightforward as it seems. Denmark has traditionally had a combination of a relatively flexible labour market and a high level of income protection: Danish workers have had little protection from dismissal, but their income has been protected. ${ }^{3}$ Economic performance under the flexicurity model has been uneven. In the early 1980s, Denmark experienced a dismal macroeconomic performance, with high and rising unemployment, high inflation, chronic current account deficits, and mounting public deficits. In the 1990s, labour market reforms were implemented to modify the flexicurity model: the maximum period for participation in active labour market programmes was reduced from eight to five years in 1998 and to four years after 2000, and the eligibility criteria for unemployment benefits were tightened. As a result, the unemployment rate fell sharply during 1993-2003.

Other countries have been able to reduce their unemployment rates to low levels with rather different social models. For example, Sweden, which is comparable to Denmark in terms of the size of its public sector and the generosity of its welfare system, has a more rigid labour market (as measured by the overall

\footnotetext{
1 Jianping Zhou: Danish for All? Balancing Flexibility with Security: The Flexicurity Model, IMF Working Paper, WP/07/36.

2 See C. Schubert, H. Martens: The Nordic Model: A Recipe for European Success?, EPC Working Paper No. 20, 2005; A. Sapir: Globalization and the Reform of European Social Models, Bruegel Policy Brief, Issue 2005/01.

${ }^{3}$ T. Wilthagen, T. Frank, H. van Lieshout: Towards "Flexicurity"?: Balancing Flexibility and Security in EU Member States, paper presented at the $13^{\text {th }}$ World Congress of the International Industrial Relations Association (IIRA), Berlin, September 2003.
} 
Figure 1

Key Elements of the Danish Flexicurity Model
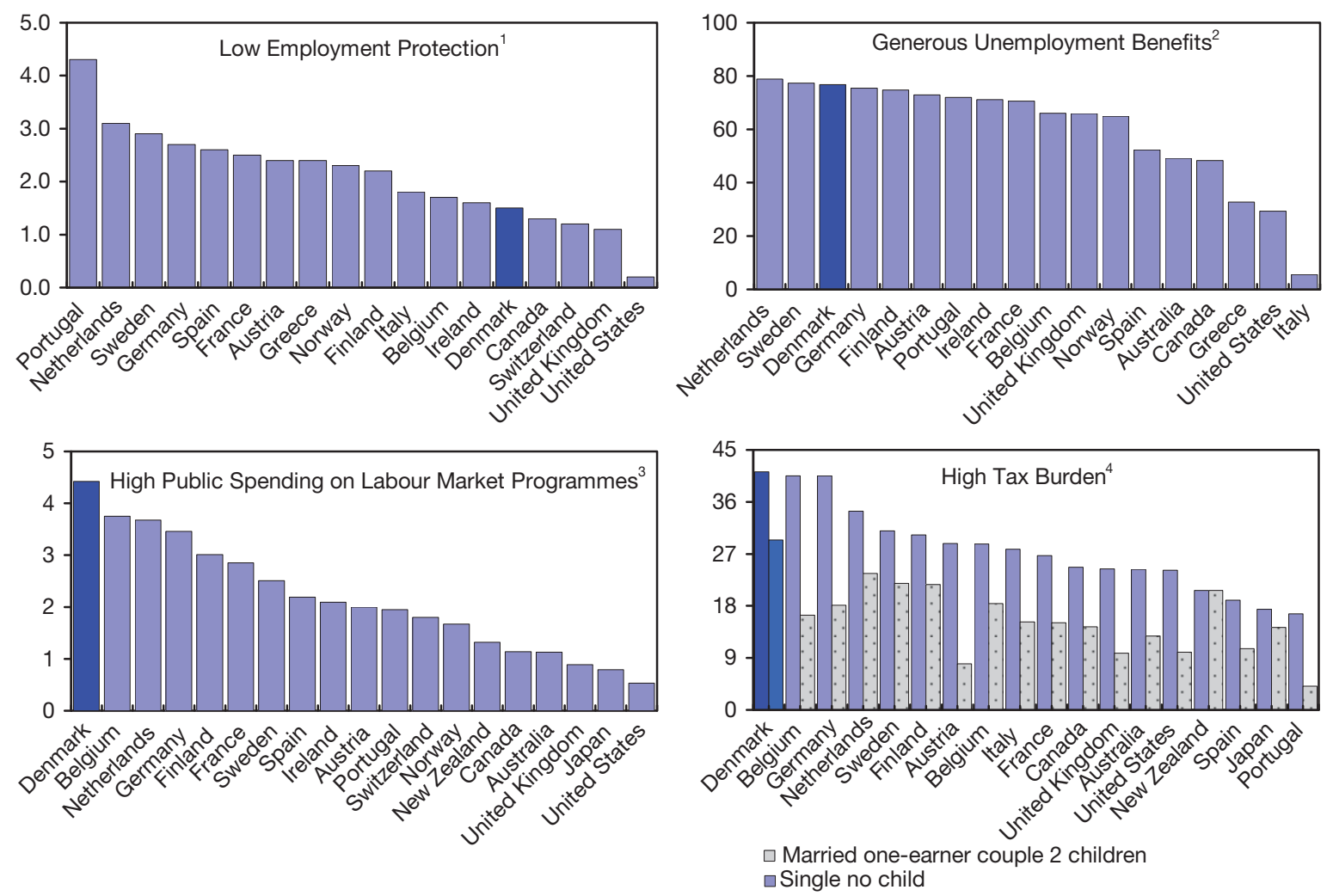

Source: OECD: Employment Outlook, Paris 2005.

1 OECD index on employment protection legislation (EPL) for regular jobs (2003). Higher numbers indicate stricter EPL.

${ }^{2}$ Average net replacement rate over 5 years of unemployment and includes social benefits (2004).

${ }^{3}$ In per cent of GDP (2003).

${ }^{4}$ Income tax plus employee contributions less cash benefits, as per cent of gross wages (2004).

strictness of protection against dismissals) than Denmark but has maintained a lower unemployment rate during most of the last 30 years. Ireland and the United Kingdom, on the contrary, have achieved substantial reductions in their unemployment rates with the "Anglo-Saxon model", characterised by relatively low employment protection and low replacement rates.

Moreover, often overlooked is the high cost of implementing the flexicurity model. Denmark has one of the largest tax wedges on labour income among European countries; this is necessary to finance its high spending on labour market programmes and unemployment benefits (more than 5 per cent of GDP). The large tax wedge reduces employment, raising the question of whether the flexicurity model efficiently combines high levels of social security and a flexible labour market. It also brings up another fundamental question: is it feasible to implement the Danish model in countries Intereconomics, March/April 2008 facing high unemployment rates and budgetary difficulties?

\section{Key Elements of the Danish Flexicurity Model}

The flexicurity model combines three key elements (see panels in Figure 1):

Labour market flexibility. Measured by the restrictiveness of employment protection legislation, the Danish labour market is more flexible than many other European countries (panel 1). In practice this means that Danish employers, in both the public and private sectors, can lay off workers relatively easily. This is not a novel aspect of the Danish social system: protection against dismissal has historically been low in Denmark, which has been linked to its openness and the large share of small and medium-sized enterprises.

An extensive social safety net. Danes enjoy a high level of social protection, including generous unemployment benefits; the average net replacement rate, 
at about 80 per cent, is among the highest in Europe (panel 2).

Active labour market policies. A large variety of active labour market programmes are in place to facilitate and create incentives for reintegration of the unemployed into the labour market. As a result, Denmark is at the top in terms of its per capita spending on labour market programmes (panel 3), largely sustained by high taxes on labour income (panel 4).

\section{Flexicurity Model and Unemployment}

The empirical evidence suggests that various elements of the Danish model tend to have different effects on unemployment. The flexible labour market helps reduce the structural unemployment rate by improving labour market dynamics, while active labour market policies also contribute to low structural unemployment rates, although this may be partly due to a well-recognised statistical problem: participants in active labour market programmes are considered as employed. Generous unemployment benefits, however, increase the structural unemployment rate by reducing incentives to work and raising reservation wages. Similarly, a large tax wedge on labour income raises unemployment through its negative effect on labour demand and labour supply. Nonetheless, the reduction in the unemployment rate in Denmark since 1993 that was due to the flexibility in the labour market and the active labour market policies appears to more than offset the negative impact of the high labour taxes on employment.

The following simple model analyses the effects of various elements of the Danish flexicurity model on unemployment.

The model consists of two equations. Equation (1) characterises the dynamics of unemployment as a function of policies:

$$
\text { (1) } u_{t}=c+\rho u_{t-1}-\alpha a l m p_{t}+\beta p / m p_{t}+\gamma e p l_{t}+\delta t w_{t}
$$

where $u_{t}$ is the structural unemployment rate; $a / m p_{t}$ is the public expenditure on active labour market policies per unemployed worker (expressed as a share of the average wage); $p / m p_{t}$ is the public expenditure on passive labour market policies (i.e. unemployment benefits) per unemployed worker (expressed as a share of the average wage); epl is a measure of the strictness of employment protection legislation; and twt is the tax wedge. All coefficients are positive.

Equation (2) gives the budget constraint: any increase in the expenditure on active or passive labour market policies is financed by a rise in taxes on labour income:

(2) $\left(1-u_{t}\right) L_{t} W_{t} t w_{t}=\left(1-u_{t}\right) L_{t} W_{t} \varnothing+u_{t} L_{t} W_{t}\left(a l m p_{t}+p^{\prime} m p_{t}\right)$

The left-hand side of the equation is the income from imposing the tax $t w_{t}$ on the wage income $\left(1-u_{t}\right)$ $L_{t} W_{t}$, where $L_{t}$ is the labour force and $W_{t}$ is the average wage. The right-hand side of the equation represents the cost of the labour market policies.

Result 1. The fiscal impact of increasing active or passive labour market policies depends on the level of the unemployment rate.

This can be shown by rewriting Equation (2) as

(3) $t w_{t}=\varnothing+\frac{u_{t}}{1-u_{t}}\left(a l m p_{t}+p l m p_{t}\right)$

Taking the derivative of Equation (3) gives

$\frac{\partial t w_{t}}{\partial a l m p_{t}}=\frac{\partial t w_{t}}{\partial p / m p_{t}}=\frac{u_{t}}{1-u_{t}}$

which implies that the fiscal impact increases more than proportionately with the unemployment level. For example, the impact of a given change in labour market policies in a country with an initial unemployment rate of 10 per cent is 2.1 times higher than that in a country with an unemployment rate of 5 per cent.

The long-run steady-state relationship between the policies and the unemployment rate is obtained by setting $u_{t}=u_{t-1}$ :

$$
\begin{aligned}
(1-\rho) u & =c+\delta \varnothing-\alpha a l m p+\beta p / m p+\gamma e p l \\
& +\delta \frac{u}{1-u}(a / m p+p / m p)
\end{aligned}
$$

This can be written as a second-order equation for the unemployment rate:

$$
u^{2}-\lambda u+\kappa=0
$$

with

$\lambda=1-\frac{c+\delta \varnothing-(\alpha+\delta) a l m p+(\beta-\delta) p l m p_{t}+\gamma e p l}{1-\rho}$

and

$$
\kappa=\frac{c+\delta \varnothing-\alpha a / m p+\beta p / m p+\gamma e p l}{1-\rho}
$$

The steady-state unemployment rate is given by Intereconomics, March/April 2008 
Figure 2

Denmark:

Unemployment Rate Convergence Toward

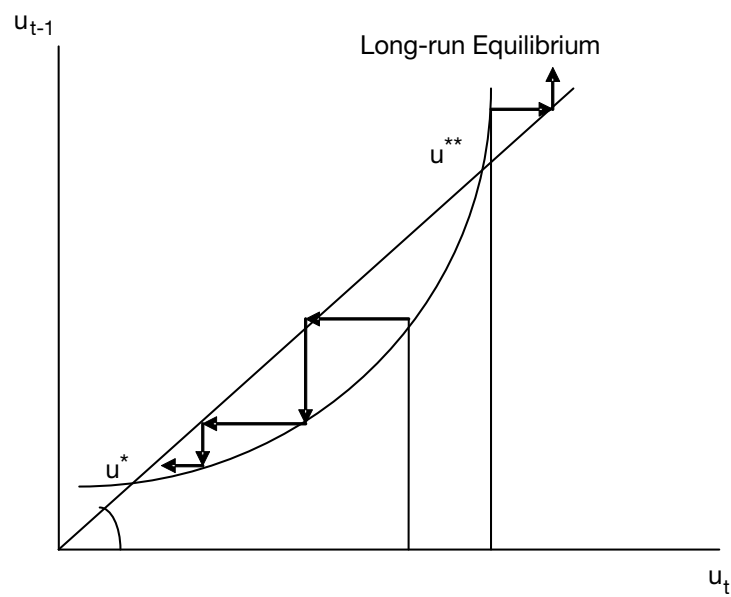

(4) $u=\frac{\lambda \pm \sqrt{\lambda^{2}-4 u}}{2}$

Result 2. There could be two equilibria unemployment rates for a given set of policies: a "good equilibrium" associated with a low unemployment rate and a small tax wedge, and a "bad equilibrium" associated with a high unemployment rate and a large tax wedge. Only the low-unemployment equilibrium is stable.

The multiple equilibria are the result of the two-way causality between the level of the unemployment rate and that of the tax wedge. A large tax wedge tends to reduce employment and increase unemployment, resulting in higher spending on unemployment benefits, which will likely result in an even larger tax wedge on labour income.

To prove that only the low-unemployment equilibrium is stable, using Equations (1) and (3), we can obtain

(5) $u_{t}^{2}-\left(\eta+\rho u_{t-1}\right) u_{t}+\rho u_{t-1}+\eta-1+\delta\left(a / m p_{t}+\beta p / m p\right)=0$

where

$\eta=1+c+\delta \varnothing-(\alpha+\delta) a l m p_{t}+(\beta-\delta) p l m p_{t}+\gamma e p l_{t}$

By differentiating Equation (5), we can obtain the first derivative of the period $t$ unemployment rate with respect to the previous period's unemployment rate:

$\frac{\partial u_{t}}{\partial u_{t-1}}=\frac{\rho}{1-\delta\left(a l m p_{t}+p / m p_{t}\right) /\left(1-u_{t}\right)^{2}}$

Since $\partial u_{t} / \partial u_{t-1}$ is increasing with $u_{t}$, this implies that if there are two equilibria, the one with the higher rate Intereconomics, March/April 2008
Figure 3

Denmark:

Impact of Active Labour Market Policies



of unemployment is unstable because $\partial u_{t} / \partial u_{t-1}>1$. The stable long-run equilibrium rate is

$u^{*}=\frac{\lambda-\sqrt{\lambda^{2}-4 u}}{2}$

and the unemployment rate $u_{t}$ converges toward $u^{*}$ (cf. Figure 2), provided that it is initially lower than

$u^{* *}=\frac{\lambda+\sqrt{\lambda^{2}-4 u}}{2}$

Result 3. The impact of active labour market policies depends on a country's initial level of unemployment and the level of the tax wedge: the unemployment rate declines in a country with a low unemployment rate and a low tax rate but rises in a country with high unemployment and a large tax wedge.

This is illustrated by Figure 3 . The horizontal line captures the right-hand side of the following equation determined by policy variables:

$\left[(1-\rho)-\frac{\delta}{1-u}(a / m p+p / m p)\right] u=c+\delta \varnothing-\alpha$ almp +

$\beta p / m p+y e p l$

The concave curve captures the left-hand side of the equation, which is influenced by the level of the unemployment rate. An increase in spending on active labour market programmes will shift the horizontal line downward. It has opposite effects on the unemployment rate: it falls in the "good" equilibrium but rises in the "bad" equilibrium. This is mainly because of the dynamics among active labour market policies, taxes, and unemployment rates. In the case where $\delta=0$ (i.e. when higher spending on active labour market programmes is not financed by higher taxes), the concave 
curve becomes a straight line, and active labour market policies would only lower the unemployment rate.

\section{Conclusions}

Should and can the Danish model be adopted by other European countries to reduce unemployment? The answer is not obvious. First, Denmark has traditionally had a combination of a flexible labour market and a high level of income protection. Nevertheless, in the early 1980s Denmark experienced high and rising unemployment and inflation, chronic current account deficits and mounting public deficits. Only after unemployment benefits and labour market policies were tightened did unemployment come down. Second, other countries in Europe have been able to reduce their high unemployment rates to low levels with rather different social models. Furthermore, often overlooked is the high cost of implementing the Danish model. As most countries that are tempted to adopt the Danish model will typically start from a high unemployment level, a move toward the Danish model will, in the short run, trigger a sharp increase in the cost of unemployment benefits and active labour market poli- cies, thereby widening the tax wedge, with an adverse impact on labour demand and supply.

Nonetheless, certain elements of the Danish model could usefully be studied and considered by other countries. Among others, they include the trade-off between the population's willingness to accept labour market flexibility and the presence of a well-functioning social safety net, and the accompanying need to develop effective labour market policies in order to avoid high costs and perverse incentives. The Danish government's constant awareness and analysis of the challenges facing the flexicurity model, and its ability to respond to them with policy action are noteworthy in this regard. For instance, since the economic crisis in the early 1980s, reforms have been implemented to shorten the maximum period for participation in active labour market programmes and tighten the eligibility criteria for unemployment benefits. In addition, the recent Welfare Agreement, agreed to in June 2006, included a number of further measures to reduce the period during which unemployment benefits are offered.

\section{Governance of the European Social Model: The Case of Flexicurity}

For long-time observers of EU social and employment policies it is hardly surprising that the concept of flexicurity has gradually become a central concern of EU reform initiatives. The linguistically awkward combination of flexibility and security into "flexicurity" succinctly captures the essence of European economic policy-making since its inception, and is a good example of the distinct character of the European Social Model: a balancing of economic and social interests that understands social and employment policy as an integral part of economic policy and as an important factor of production in the European economy.

Furthermore, flexicurity policies are a paradigm case of the new approach taken to regulating social and employment law in the European Union. Flexicurity forms part of a drive to introduce new modes of governance and a greater reliance on soft law instru-

* Associate Professor, Warwick University, United Kingdom. ments in European policy-making, which were outlined in the White Paper on Governance introduced by the European Commission. ${ }^{1}$ It will be argued in the following that we can increasingly observe elements of reflexivity in these supranational policy-making efforts. The central thesis of this article is that in order for soft forms of governance to be effective, European law and policy must become reflexive. In the areas of European social and employment policies, flexicurity and the debate over a European Social Model play an important role in this process.

\section{From Open to Reflexive Coordination}

The introduction of new forms of governance in the EU has fundamentally changed the regulation of social and employment law and policy-making in the EU. The steps taken in adjusting economic policies in prepara-

1 European Commission: White Paper on European Governance, $\operatorname{COM}(2001) 428$ final.

Intereconomics, March/April 2008 
tion for the European Economic and Monetary Union (EMU) during the 1990s and its launch in 2002 resulted in a reorientation of European policy-making in general. It entailed a fundamental change of methods of governance at the supranational level. ${ }^{2}$ The coordination of fiscal policies served as the model for the introduction of new policies of coordination of employment in the form of the European Employment Strategy (EES), ${ }^{3}$ and for the introduction of coordination policies in various social policy fields as well.

The main tenets of the new governance approach were outlined by the Commission in the already mentioned White Paper on European Governance. In it the Commission promised a fundamental reform of European governance through an increased use of the open method of coordination (OMC). The nature of the $\mathrm{OMC}$ was seen as conducive to the achievement of policy goals in areas where hard legislative competences were lacking. Furthermore, it was viewed as a way of encouraging cooperation and exchange of best practices among member states. It operates through common targets implemented in guidelines adopted at the supranational level to which member states have to respond, for example, by establishing national action plans as in the case of employment and social policy. The member state reactions are regularly monitored by the Commission in order to establish whether progress has been made to meet established targets. An important goal of the new governance approach is that it allows member states to compare their efforts and to learn from one another's experiences.

Two types or sets of OMCs can be distinguished. The first group consists of coordination policies that are mentioned in the Treaty, that foresee strong participation of the Commission, and that allow the use of pressure on the member states. The Broad Economic Policy Guidelines and the European Employment Guidelines belong to this first group. The second group is characterised by a lack of a Treaty basis, a weaker role for the Commission, less pressure on the member states and greater respect of national values. ${ }^{4}$ The OMCs in the area of social protection (pension, social inclusion, and health) belong in this second group.

\footnotetext{
2 See G. De Burca, J. Scott (eds.): Law and New Governance in the EU and the US, Oxford 2006, Hart.

${ }^{3}$ See D. Ashiagbor: EMU and the Shift in the European Labour Law Agenda: from 'Social Policy' to 'Employment Policy', in: European Law Journal, Vol. 7, No. 3, 2001, pp. 311-330; D. A s hia g bor: The European Employment Strategy: Labour Market Regulation and New Governance, Oxford 2005, Oxford University Press.

4 C. de Ia Porte: The Soft Open Method of Co-Ordination in Social Protection, in: European Trade Union Yearbook 2001, pp. 339-362 (here p. 340), 2001.
}

Intereconomics, March/April 2008
Several changes have occurred as a result of adopting the OMC and other forms of new governance. In contrast to the Classical Community Method of topdown governing by central institutional actors leading to binding, uniform or harmonised rules, the new methods of governance rely on non-hierarchical and flexible modes of governance that favour dialogue between the actors involved. They favour horizontal over vertical relations of the main European institutions, such as the Commission, Parliament, and the European Court of Justice, with member states, local and regional actors, the social partners, and other civil society representatives. Furthermore, as far as implementation is concerned, the legal nature of the instruments regulating policy has changed from reliance on hard to reliance on soft law measures. ${ }^{5}$

The extension of the use of OMCs in a multiplicity of fields has led to an increase in complexity that has already brought about new thinking about OMCs at the European level. The OMC in employment, for example, was redesigned in 2003. Its reform addressed the problems of effectiveness, legitimacy, and visibility ${ }^{6}$ by calling for a broader set of actors to be involved at the level of the member states. Some of the concerns about the operation of the EES, such as the lack of qualitative dimensions of indicators and insufficient support for mutual learning, voiced for example by Günther Schmid and Silke Kull, ${ }^{7}$ who echo issues raised in the 2003 and 2004 Kok Reports, ${ }^{8}$ were addressed in the 2003 reform of the Employment Guidelines. Other issues, such as the specificity of employment policy targets and democratic participation, remain problematical.

In addition, the operation of a variety of OMCs alongside each other was seen as too complex for both the European institutions and the member states. A new reflexive thinking led to streamlining and 'co-

\footnotetext{
5 See D. M. Trubek, P. Cottrell, M. Nance: 'Soft Law', 'Hard Law' and EU Integration, in: G. De Burca, J. Scott (eds.), op. cit. pp. 65-94; D. M. Trubek, L. G. Trubek: Hard and Soft Law in the Construction of Social Europe: the Role of the Open Method of Coordination, in: European Law Journal, Vol. 11, 2005, pp. 343-364.

${ }^{6}$ C. Kilpatrick: New EU Employment Governance and Constitutionalism, in: G. De Burca, J. Scott (eds.), op. cit., pp. 121-151 (here pp. 140-142)

7 See G. Schmid, S. Kull: Die Europäische Beschäftigungsstrategie. Perspektiven der Offenen Methode der Koordinierung, in: $\mathrm{H}$ Kaelble, G. Schmid (eds.): Das europäische Sozialmodell. Auf dem Weg zum transnationalen Sozialstaat, WZB-Jahrbuch 2004, Berlin 2004, Sigma, pp. 317-343 (here pp. 338-339).

8 Jobs, Jobs, Jobs. Creating more employment in Europe. Report of the Employment Taskforce chaired by Wim Kok, November 2003 and Facing the Challenge. The Lisbon strategy for growth and employment. Report from the High Level Group chaired by Wim Kok, November 2004
} 
ordination of coordination' policies. ${ }^{9}$ The idea of connecting economic, employment, and social OMCs so that these policies might reinforce one another has partially become reality. In 2005, as a result of a critical assessment of the OMCs in economic and employment policies, particularly with respect to their concrete effects on unemployment as well as employment rates, and as a measure to increase the chances of reaching the Lisbon targets (also referred to as a relaunch of Lisbon), the Broad Economic Policy Guidelines (BEPG) and the Employment Guidelines were combined into the Integrated Economic and Employment Guidelines..$^{10}$ This meant the creation of a unified timetable that accompanied the switch from one-year to three-year cycles that was already agreed to in 2003 (the first cycle started in 2003 and the second in 2006).

Moreover, there is "coordination of coordination" in the form of the ongoing streamlining of the social policy OMCs. Streamlining the social policy OMCs is meant as the promotion of the effective operation of the policy triad of economic, employment and social policies, and follows the model of the streamlining of economic and employment policies. The goal was to modernise social protection systems by making coordination of social protection more effective. Initially, the streamlining and simplifying of the social policy OMCs was confined to the method alone by providing a clearer definition of the scope of OMCs. However, streamlining of policy coordination was expanded ${ }^{11}$ and started to become an effort linked to the overarching goal of improving the quality and stability of the socio-economic governance of the EU as a whole. The right policy mix was supposed to create a "virtuous circle" of economic and social progress.

A major innovation resulting from the streamlining of social policy is the Joint Social Protection Report of the Commission and the Council. In 2005 this new report replaced the Social Protection in Europe Report, as well as the joint reports on social inclusion, pensions, and policy cooperation in healthcare and long-term care. The contribution of the member states changed accordingly. Since 2006, member states have to pre-

\footnotetext{
${ }^{9}$ See R. Rogowski: Reflexive Coordination. Thoughts on the European Social Model, Jean Monnet Working Paper, NYU School of Law, (forthcoming).

10 See H. Jørgensen: The European Employment Strategy up for Revision - Effective Policy or European Cosmetics? in: T. Bredgaard, F. Larsen (eds.): Employment Policy from different Angles, Copenhagen 2005, DJØF Publishing, pp. 23-46.

11 The Commission had already proposed a linkage of the various social policy OMCs in 2003 in its Communication "Strengthening the social dimension of the Lisbon strategy: Streamlining open coordination in the field of social protection", COM(2003) 261 final.
}

pare National Action Plans that cover all three social policy fields together. ${ }^{12}$

There is a growing body of research that critically assesses the OMC. Doubts have been raised, for example, concerning the implementation process of the EES, alleging that the production of the National Action Plan often involves nothing more than technocrats and government officials. ${ }^{13}$ Furthermore, sociological accounts of the monitoring process see it riddled with cultural misunderstandings and linguistic ambiguities. ${ }^{14}$ Yet it is crucial for an adequate understanding of the development of coordination policies to be clear about the Commission's overarching concern of linking European coordination effects with the reform of welfare policies in the member states. The aim of streamlining economic employment, and social policies at the supranational level is to support the member states in modernising and further developing their national social protection systems. The Commission has invested high hopes in the improved exchange of information and the creation of opportunities for mutual learning in order to promote national reform processes. ${ }^{15}$ In this context awareness is growing that European policies have to become reflexive and adopt an understanding expressed by reflexive theories of law and regulation. In other words, in order to be effective, legal regulation has to realise its limits and switch from top-down regulation to modes that support self-regulation.

\section{Flexicurity within the Context of New Governance of the European Union}

Any coordination of policies has to deal with a paradox. It has to recognise and preserve the differences in welfare regimes and regulatory styles and economic traditions, while at the same time paying attention to the unifying aspects on which coordination efforts can be based. The European Commission has embarked on a number of attempts to provide ideas on these unifying aspects of social and welfare, as well as economic polices. Prominent examples among these

12 The 2007 Joint Social Protection Report was the first report that evaluated integrated National Reports on strategies for social inclusion, pensions, healthcare and long-term care.

13 See J. Zeitlin: The Open Method of Coordination in Action. Theoretical Promise, Empirical Realities, Reform Strategy, in: J. Zeitlin, P. Pochet, L. Magnus s on (eds.): The Open Method of Co-ordination in Action, in: The European Employment And Social Inclusion Strategies. Bruxelles 2005, Peter Lang, pp. 447-503 (here p. 460).

14 See C. Barbier: Research on 'Open Methods of Coordination' and National Social Policies. What Sociological Theories and Methods? in: T. Bredgaard, F. Larsen (eds.), op. cit., pp. 47-74.

15 Presidency Conclusions on the social dimension of the revised Lisbon strategy at the Informal EPSCO Council Meeting Villach, 20 January 2006, http://www.eu2006.bmsg.gv.at/cms/eu2006EN/detail.htm? channel $=\mathrm{CH} 601 \&$ doc $=\mathrm{CMS} 1137851810205$. 
are the concept of flexicurity and the European Social Model.

Flexicurity is a policy concept that was initially promoted by social-democratic politicians such as Poul Nyrup Rasmussen, the Danish Prime Minister from 1992 until 2001. It was implemented in Denmark in the early 1990s and, with some variations, in other Nordic countries with strong traditions of social dialogue. In addition to Denmark, the Dutch labour market policy is widely seen as guided by flexicurity concerns, the most obvious example being the Dutch Flexibility and Security Act of 1999. In fact, the policies of these two countries are actively promoted by the European Commission as examples of policies from which other member states can learn. ${ }^{16}$

During 2006 and 2007 the European Commission adopted the view that flexicurity is a key policy concept in fostering the "modernisation" of welfare policies. At its Spring Summit 2006 in Brussels, the European Council listed flexicurity in its Presidency conclusions as a measure to increase employment opportunities for priority categories, and promised the establishment of a set of common principles on flexicurity:

“... the European Council asks member states to direct special attention to the key challenge of 'flexicurity' (balancing flexibility and security): Europe has to exploit the positive interdependencies between competitiveness, employment and social security. Therefore member states are invited to pursue, in accordance with their individual labour market situations, reforms in labour market and social policies under an integrated flexicurity approach, adequately adapted to specific institutional environments and taking into account labour-market segmentation. In this context, the Commission, jointly with member states and social partners, will explore the development of a set of common principles on flexicurity. These principles could be a useful reference in achieving more open and responsive labour markets and more productive workplaces." 17

In June 2007 the European Expert Group on Flexicurity presented its report on "pathways" to flexicurity, ${ }^{18}$

\footnotetext{
16 See H. Jørgensen, P. K. Madsen: Flexicurity and Beyond-Reflections on the nature and Future of a Political Celebrity, in: H. Jørgensen, P. K. Madsen, (eds.): Flexicurity and Beyond. Finding a new agenda for the European Social Model, Copenhagen 2007, DJøF Publishing, pp. 7-35.

17 Brussels European Council: Presidency Conclusions, 23-24 March 2006, 7775/06 CONCL 1, Part One, Specific Areas for Priority Action, (c) Increasing employment opportunities for priority categories.

18 Flexicurity Pathways - Turning hurdles into stepping stones. Report by the European Expert Group on Flexicurity: http://ec.europa.eu/employment_social/employment_strategy/pdf/flexi_pathways_en.pdf.
}

Intereconomics, March/April 2008 which suggested four strategies or "pathways" to increase flexicurity arrangements:

- Pathway 1: Tackling contractual segmentation

- Pathway 2: Developing flexicurity within enterprises and offering transition security

- Pathway 3: Tackling skills and opportunity gaps among the workforce

- Pathway 4: Improving opportunities for benefit recipients and informally employed workers.

The Commission responded immediately at the end of June 2007 with a Communication to the European Parliament, the Council, the European Economic and Social Committee and the Committee of the Regions, entitled "Towards Common Principles of Flexicurity: more and better jobs through flexibility and security". ${ }^{19}$ In it the Commission endorsed the four pathways to flexicurity policies suggested by the Expert Group and translated them into four policy components that need to be taken into consideration in designing and implementing flexicurity policies:

- flexible and reliable contractual arrangements (from the perspective of the employer and the employee, of "insiders" and "outsiders") through modern labour laws, collective agreements and work organisation;

- comprehensive lifelong learning (LLL) strategies to ensure the continual adaptability and employability of workers, particularly the most vulnerable;

- effective active labour market policies (ALMP) that help people cope with rapid change, reduce unemployment spells and ease transitions to new jobs;

- modern social security systems that provide adequate income support, encourage employment and facilitate labour market mobility. This includes broad coverage of social protection provisions (unemployment benefits, pensions and healthcare) that help people combine work with private and family responsibilities such as childcare. ${ }^{20}$

The Council on Employment, Social Policy, Health and Consumer Affairs, while explicitly referring to the Commission's Communication and to findings of the Conference on "Flexicurity: Key Challenges" held in Lisbon on 13/14 September 2007, adopted on 6 December 2007 the following eight Common Principles of Flexicurity.

19 Towards Common Principles of Flexicurity: more and better jobs through flexibility and security. Communication from the Commission to the European Parliament, the Council, the European Economic and Social Committee and the Committee of the Regions, adopted on 27 June 2007, COM(2007) 359 final.

20 Ibid., p. 12. 
1. Flexicurity is a means to reinforce the implementation of the Lisbon Strategy, create more and better jobs, modernise labour markets, and promote good work through new forms of flexibility and security to increase adaptability, employment and social cohesion.

2. Flexicurity involves the deliberate combination of flexible and reliable contractual arrangements, comprehensive lifelong learning strategies, effective active labour market policies, and modern, adequate and sustainable social protection systems.

3. Flexicurity approaches are not about one single labour market or working life model, nor about a single policy strategy: they should be tailored to the specific circumstances of each member state. Flexicurity implies a balance between the rights and responsibilities of all concerned. Based on the common principles, each member state should develop its own flexicurity arrangements. Progress should be effectively monitored.

4. Flexicurity should promote more open, responsive and inclusive labour markets overcoming segmentation. It concerns both those in work and those out of work. The inactive, the unemployed, those in undeclared work, in unstable employment, or at the margins of the labour market need to be provided with better opportunities, economic incentives and supportive measures for easier access to work or stepping-stones to assist progress into stable and legally secure employment. Support should be available to all those in employment to remain employable, progress and manage transitions both in work and between jobs.

5. Internal (within the enterprise) as well as external flexicurity are equally important and should be promoted. Sufficient contractual flexibility must be accompanied by secure transitions from job to job. Upward mobility needs to be facilitated, as well as between unemployment or inactivity and work. High-quality and productive workplaces, good organisation of work, and continuous upgrading of skills are also essential. Social protection should provide incentives and support for job transitions and for access to new employment.

6. Flexicurity should support gender equality, by promoting equal access to quality employment for women and men and offering measures to reconcile work, family and private life.

7. Flexicurity requires a climate of trust and broadlybased dialogue among all stakeholders, where all are prepared to take the responsibility for change with a view to socially balanced policies. While public authorities retain an overall responsibility, the involvement of social partners in the design and implementation of flexicurity policies through social dialogue and collective bargaining is of crucial importance.

8. Flexicurity requires a cost effective allocation of resources and should remain fully compatible with sound and financially sustainable public budgets. It should also aim at a fair distribution of costs and benefits, especially between businesses, public authorities and individuals, with particular attention to the specific situation of SMEs.

These Common Principles of Flexicurity were endorsed by the European Council on 14 December 2007.

It is fair to say that in the conduct of social and employment polices at the European level the concept of flexicurity now plays the key role. It has become a central policy instrument in the EU's Social Agenda 2005-2010, and its use in the coordination of employment policies dovetails with several other Commission initiatives. For example, it plays a main role in efforts to review current labour law systems in the EU. The European Commission issued a Green Paper on Modernising labour law to meet the challenges of the 21st century at the end of November 2006 and launched a broad public debate on the regulation of non-standard contracts or self-employed in the European workplace. The Green Paper explicitly directs member states, employers and workers' representatives to assess how labour law at EU and national level can help the job market become more flexible while improving security for workers (the flexicurity approach).

However, a number of critical aspects can (still) be noted with respect to the use of the concept of flexicurity in documents such as the Presidency Conclusions, the Council Conclusions on Common Principles of Flexicurity or the Green Paper on the reform of labour law. These include the following considerations.

- The term flexicurity has to remain an aspiration rather than being identified with a concrete policy, despite efforts to define common flexicurity principles and translate them into employment and other policy measures.

- For the success of flexicurity policies it seems crucial that the definition of the term flexicurity remain vague so that it can be used to address a range of sometimes contradictory policy goals.

- The success of the concept of flexicurity also depends on an imbalance in perception that guarantees that the positive connotations of balancing (of interests), integration (of different reform efforts), and

Intereconomics, March/April 2008 
inclusion (of actors) outweigh any allegations of negative consequences or a cover-up for deregulation policies in new disguise.

- Flexicurity must be perceived as an opportunity, adding urgency to the need for labour market and social policy reforms, that can overcome caution and restraint in reforming established systems of welfare protection.

So far, the academic debate on flexicurity is largely confined to discussions of national models of labour market reform in selected countries of the European Union. It is predominantly comparative and tends to link flexicurity policies to particular welfare regimes. Of the four models in the world of welfare (Nordic, liberal, corporatist and Mediterranean), it is the Nordic model that has the most potential for adopting flexicurity policies.

However, the Communication on Common Flexicurity Principles makes efforts to present the concern with flexicurity as a widespread policy concern throughout the European Union. It lists a number of examples of successful flexicurity policies. These include the Austrian severance pay system; the "Golden Danish Triangle", i.e. flexible contractual arrangements, generous social security and welfare schemes, combined with extensive active labour market policies; temporary work in the Netherlands; measures to reduce fixedterm contracts in Spain; and the Irish social partner agreement "Towards 2016". ${ }^{21}$ Probably the most prominent legislative initiative is the Dutch Flexibility and Security Act of 1999. It "balances" a reduction of employment protection for employment in standard employment relations (shortening of notice periods and easing of dismissal procedures) and agency work (indefinite contracts allowed) with new rights granted to atypical workers (contractual rights for on-call and agency workers). ${ }^{22}$

It is thus not surprising that main theoretical contributions to analysing the flexicurity concept originated in the Netherlands. In Ton Wilthagen's ${ }^{23}$ assessment,

\footnotetext{
21 Ibid., ANNEX II EXAMPLES OF FLEXICURITY.

22 See the "case study" of the Dutch Flexibility and Security Act of 1999 in T. Wilthagen, M. Houwerzijl: How does flexibility affect social cohesion? in: Council of Europe (ed.): Reconciling labour flexibility with social cohesion - Facing the challenge. Trends in social cohesion, No. 15, Strasbourg 2005, pp. 109-131, in particular Table 2 : Central Aspects of the Dutch Flexibility and Security Act on p. 119.

23 Ton Wilthagen chaired the European Expert Group on Flexicurity. See his theoretical assessment of flexicurity in T. Wilthagen: Striking a Balance? Flexibility and Security in European Labour Markets, in: T. Bredgaard, F. Larsen (eds.), op. cit., pp. 253-267; and T. Wilthagen, F. Tros: The concept of 'flexicurity': a new approach to regulating employment and labour markets, in: Transfer, Vol. 10, No. 2 2004, pp. 166-186.
}

Intereconomics, March/April 2008 flexicurity is both a policy concept and an analytical framework. In his account flexicurity includes external and internal numerical flexibility as well as functional and wage flexibility on the flexibility side, and job, employment, income, and "combination" security on the security side. He emphasises the possibility of the mutual support of flexibility and security resulting in gains for both employer and employees.

In normative debates we find surprisingly few voices that criticise and warn against the dangers of flexicurity policies. Leschke, Schmid and Griga ${ }^{24}$ mention the possibility of a vicious nexus of flexibility and security leading to a downward spiral and losses for both employer and employee. They suggest integrating the flexicurity concept with a transitional labour market policy approach. Flexicurity policies would then form part of a dynamic perspective of life-course and career changes (transitions). They also emphasise the potential of combining European and national flexicurity policies and making use of the social dialogue:

"... chance that it could be the vehicle to revitalise the social dialogue and promote the negotiation of new topics between the social partners, both at national and European level. The improvement of employment security, by establishing branch specific collective training funds, or facilitating complementary relations between flexibility and security in the course of people's lives, seem to be issues for negotiations where all sides could win in the long run." 25

In focusing on new forms of employment and the flexibilisation of existing institutional and legal structures in order to cope with new social risks, flexicurity is indeed closely related to debates about transitional labour markets that focus on solutions to the flexibilisation of employment in order to ease transitions in and out of the labour market. ${ }^{26}$ In a certain sense the flexicurity concept continues the older debate over the reconciliation of efficiency and equity concerns. ${ }^{27}$ However, what is new in the flexicurity debate is its connection to new forms of governance, and a focus

\footnotetext{
24 J. Leschke, G. Schmid, D. Griga: On the Marriage of Flexibility and Security: Lessons from the Hartz reforms in Germany, in: H. Jørgensen, P. K. Madsen (eds.), op. cit., pp. 335-364 (here pp. 342-344).

25 Ibid., p. 360.

26 See B. Gazier: Making transitions pay: the 'transitional labour markets' approach to 'flexicurity', in: H. Jørgensen, P. K. Mads en (eds.), op. cit., pp. 99-130.

27 See for example G. Sch mid: Flexibilization of the Labour Market through Law? On Equity and Efficiency in the Regulation of WorkingTime, in: R. Rog ow ski, T. Wilth a gen (eds.): Reflexive Labour Law. Studies in Industrial Relations and Employment Regulation, Deventer 1994, Kluwer, pp. 317-343.
} 
on the procedural aspects of implementing flexicurity policies.

The flexicurity debate is very much in line with a reflexive style of policy-making. Suggestions to improve flexicurity policies, such as defining performance indicators, increased screening or monitoring policies, and support for the diffusion of best practices, are examples of a procedural style of law and policy-making. They are facilitative measures that aim at triggering and inducing externally processes of self-regulation. Thus flexicurity blends well with the European Union's new governance approach.

\section{Flexicurity and Coordination Policies within the European Social Model}

There is considerable overlap between the discourse on flexicurity and the debate over a European Social Model (ESM). It is suggested here that the debates over an ESM as well as flexicurity are closely connected with the new governance approach adopted by the Commission. The ESM discourse is supposed to provide the main unifying aspects of the coordination policies mentioned above. Furthermore, it indicates key policy goals of the wider project of a political European Union.

There are a number of background factors that have influenced the ESM debate. The ESM is an integral part of the ambitious project of a European Union that is capable of coordinating a wide range of policies, including the economic and employment as well as immigration, energy, and foreign and security policies of the member states. The ESM is central to the general move from negative to positive integration within the European Union. In Fritz Scharpf's analysis, positive integration requires the "reconsideration of the legal scope of negative integration in the light of social and political goals other than the maximisation of market competition". ${ }^{28}$ Or to use the Commission's language, European integration and coordination policies "must ... be seen from the perspective of European citizenship and the building of a Social Europe."29

Since the beginning of the 1990s the European Commission has adopted the rhetoric of working towards a European Social Model. Over the last ten or fifteen years it has maintained that the modernisation of this model has to be an important future target in the European Union. Indeed, the current (March 2008)

\footnotetext{
28 F. W. Scharpf: Governing in Europe: Effective and Democratic? Oxford 1999, Oxford University Press, p. 160.

29 Amended proposal for a Regulation of the European Parliament and of the Council on Coordination of Social Security Systems, COM(2003) 596 final.
}

Mission Statement of the Directorate-General for Employment, Social Affairs and Equal Opportunities starts with the opening remark that it "has the task of contributing to the development of a modern, innovative and sustainable European Social Model with more and better jobs in an inclusive society based on equal opportunities". ${ }^{30}$

In the Commission's pronouncements the ESM is portrayed as a unique blend of economic and social aims. Competitiveness is said to be coupled with social justice and the improvement of living and working standards, more jobs with better jobs. It is acknowledged that the ESM "escapes precise definition", but that nonetheless "the notion of 'model' is significant because it is 'anticipatory' or 'aspirational'." "31 The lack of coherence and theoretical distinction in referring to the ESM is compensated for by an enumeration and description of competences and policies pursued by the European institutions.

In the Commission's view, the ESM is the main feature that distinguishes the EU from the rest of the world. In its Communication on European Values in the Globalised World ${ }^{32}$ it stresses that the social models adopted in member states are based on distinctly European characteristics. Four features are identified in particular:

"First, national economic and social policies are built on shared values such as solidarity and cohesion, equal opportunities and the fight against all forms of discrimination, adequate health and safety in the workplace, universal access to education and healthcare, quality of life and quality in work, sustainable development and the involvement of civil society. These values represent a European choice in favour of a social market economy. They are reflected in the EU treaties, its action and legislation, as well as in the European Convention of Human Rights and our Charter of fundamental rights.

Second, European citizens have greater expectations of the state than their equivalents in the Asia or America. The public sector tends to play a big role, either through regulation or government spending, in the organisation and financing of national systems.

\footnotetext{
30 http://ec.europa.eu/dgs/employment_social/index_en.htm.

31 Quotes from a speech of the then Commissioner responsible for Employment and Social Affairs delivered at the Labour Party Conference, Bournemouth, 29 September 2003. A. Diamantopoulou: The European Social Model - Myth or Reality?, 2003, http://ec.europa. eu/employment_social/speeches/2003/ad290903_en.pdf.

32 European Values in the Globalised World, Communication from the Commission to the European Parliament, the Council, the European Economic and Social Committee and the Committee of the Regions, 20.10.2005, COM(2005) 525 final.
} 
In addition, all member states have played a strong role in the delivery of high quality services of general interest which have been a key feature of economic and social development. On average, the $25 \mathrm{EU}$ member states devote $27 \%$ of GDP to public spending on social protection, compared to $15 \%$ in the United States and $17 \%$ in Japan.

Third, a strong "European dimension" reinforces national systems. In contrast to other regions of the world, national systems here are reinforced by European level policies (such as the stability offered by macro-economic policy, the dynamism created by the internal market and the social agenda, and the cohesion promoted by EU Structural Funding).

Fourth, there is a strong tradition of social dialogue and partnership between governments, industry and trade unions - even if the detailed mechanisms vary considerably between member states. At a European level, this has been reflected in the EU Treaties and, for example, the regular Tripartite Social Summits." ${ }_{33}$

To a certain degree the document manages to identify underlying assumptions involved in the distinct approach followed in economic and social policy-making in the EU. It stresses the integration of social policies and the key role these play in the European economy. However, the document is less clear in identifying the function and the core elements of the specific ESM of the EU. In the debate over this distinct ESM some view it as an ideal type, some as a reality, and some as a political project. ${ }^{34}$ In academic debates we can distinguish two main approaches. One approach argues that the ESM expresses special political attitudes based on solidaristic social values that are constitutive to European economic policy-making. The alternative

33 Ibid, pp. 4-5 (emphasis in the original).

34 See, for example, A. Giddens, P. Diamond, R. Liddle (eds.): Global Europe, Social Europe. Cambridge 2006, Polity; M. Jepsen, A. Serrano Pascual: The European Social Model: an Exercise in Deconstruction, in: Journal of European Social Policy, Vol. 15, No. 3 2005, pp. 231-245; C. Offe: The European Model of 'Social' Capitalism: Can it Survive European Integration? in: The Journal of Political Philosophy, Vol. 11, No. 4, 2003, pp. 437-469; R. Rogowski (ed.): The European Social Model. Law and Policy of Transitional Labour Markets (forthcoming). Aldershot, Ashgate; F. W. Sc harpf: The European Social Model: Coping with the Challenges to Diversity, in: Journal of Common Market Studies, Vol. 40, No. 4, 2002, pp. 645-670; G.

Sch mid: Transitional labour markets and the European social model: towards a new employment compact, in: B. Gazier, G. Schmid, (eds.): The Dynamics of Full Employment. Social Integration through Transitional Labour Markets, Cheltenham 2002, Edward EIgar, pp. 393-435; K. Siss on: The "New" European Social Model: the End of the Search for an Orthodoxy or Another False Dawn? in: Employee Relations, Vol. 21, No. 5, 1999, pp. 445-462; W. Streeck: Competitive Solidarity: Rethinking the European Social Model, MPIfG Working Paper 99/8, Cologne 1999, Max-Planck-Institut für Gesellschaftsforschung; J. Wickham: The End of the European Social Model: Before It Began? Working Paper of the Irish TUC, Dublin 2002. approach emphasises its role in relation to economic efficiency. A prominent example of the second type of argument is Claus Offe's account of the ESM. He argues that notions related to the ESM constitute the very core of the distinct European political economy of the EU. ${ }^{35}$ In this view the success of any further economic integration of the European economy depends on increased attempts to coordinate social protection and to combat social and economic insecurity and social exclusion, even if this can only be achieved on a "neo-voluntary" basis, as Wolfgang Streeck has sceptically pointed out. ${ }^{36}$ At stake is the unity of the European Union in economic terms and the protection of Europe as an economic community. The disparity between social protection systems, particularly in the resulting labour costs, places certain states at a disadvantage and is harmful to the Community as a whole, thus providing further incentives to coordinate social policies. ${ }^{37}$

Anton Hemerijck has gone a step further in his analysis of the ESM. He argues that the EU's main function in bringing about social integration is that of a facilitator in reforming welfare, and in assisting processes of self-transformation of national welfare policies through coordination. ${ }^{38}$ The key idea is that of a close connection between economic and social development. This approach represents a shift from a normative to a cognitive understanding of the ESM. In cognitive terms the ESM not only promotes social justice but contributes to economic growth. Social policy is no longer considered an obstacle but a beneficial economic factor that creates security for economic activities and provides, among other benefits, incentives to pursue collective goods. ${ }^{39}$ If this cognitive understanding is shared widely, it creates an ideal basis for the development of reflexive coordination and other reflexive policymaking.

It is apparent that the ESM has to combine contradictory sets of values. On the one hand, there is reduced public expenditure for social services, financial sustainability, competitiveness, deregulation, flex-

\footnotetext{
35 C. Offe, op.cit.
}

${ }^{36}$ W. Stree ck: Neo-Voluntarism: A New European Social Policy Regime? in: G. Marks et al.: Governance in the European Union, London et al., 1996, Sage, pp. 64-94.

37 C. Offe, op. cit., pp. 458-460.

38 A. Hemerijck: Recasting Europe's Semi-Sovereign Welfare States and the Role of the EU, Paper delivered in the WZB seminar series "The European Social Model" on 16 December 2004, Berlin.

39 A. Hemerijck: The Self-Transformation of the European Social Model(s), in: G. Esping-Andersen, D. Gallie, A. Hemerijck, J. Myles (eds.): Why We Need a New Welfare State, Oxford 2002 Oxford University Press, 2002, pp. 173-213 (here p. 173-174). 
ibility, privatization and individual responsibility - key concepts in neo-liberal economic policies. But on the other, these values are crucially combined in the ESM with positive values such as security, an inclusive society, and adaptability. Or in the language of the Presidency Conclusions of the Barcelona European Council: "The ESM is based on good economic performance, high level of social protection, education and social dialogue". ${ }^{40}$ This is indeed the ideological background of flexicurity policies.

And so, a proper assessment of the European Social Model needs to look not only at its contradictory content but at its function as well. The ESM has a number of specific characteristics in this respect that distinguish it from any national welfare model. Three functional aspects of the ESM can be highlighted: its multi-layered structure, its decentralised and plural nature, and its reflexive style of policy-making.

First, the ESM consists of a multi-layered structure. The European Union as such is not the main player in devising and delivering social and employment policies. The responsibility for carrying out and financing these policies rests with the member states and they ultimately retain control. The European Union only assists the member states and acquires competences beyond coordination only in rather specific areas. Decision-making and the provision of welfare and protection is inherently decentralised in the European Union. Even the most sophisticated, centralised coordination efforts cannot change this fact; and decentralisation is widely viewed as a positive feature, indeed appreciated as a major virtue of the model. Coordination is not disguised harmonisation. It is deliberately designed to preserve the right of the member states to be the ultimate decision-makers, as is embodied in the subsidiarity principle.

Second, the ESM is pluralistic. It does not consist of one, but of several models. The pluralistic nature of the ESM supports both homogeneity and diversity. The ESM does not favour a European federal welfare state that replaces national welfare approaches, but instead encourages "competitive federalism" 41 in its coordination policies. Depending on the intensity of the role of state intervention, it is possible to distinguish four basic social security models that are in operation in a

40 Barcelona European Council, Presidency Conclusions, 15-16 March 2002, p. 8, http://www.consilium.europa.eu/ueDocs/cms_Data/docs/pressData/en/ec/71025.pdf.

41 C. Barnard: Regulating Competitive Federalism in the European Union? The Case of EC Social Policy, in: J. Shaw (ed.): Social Law and Policy in an Evolving European Union, Oxford 2000, Hart, pp. 49-69. variety of combinations among the member states. In the statist model the state is responsible for providing welfare financed out of general taxes. In the solidaritybased social insurance model, the role of the state is to provide general regulation under which employees are insured against social risks, and employers and employees are obliged to pay contributions. In the corporatist model the state supports the regulation of welfare through collective or company agreements between trade unions or employee representatives and employer associations or companies. Finally, under the individualist solution, favoured by neo-liberal economic policies, protection against risks is left to the individual seeking it through private insurance, thereby reducing the role of the state to granting tax relief or other concessions.

The third functional aspect of the ESM is that it is characterised by reflexive policy-making and the use of reflexive legal instruments. In practicing OMC the EU makes creative use of its limits, particularly of its limited legal competences. The OMC is policy-making in the absence of hard legal competences. In fact, the EU takes advantage of the absence of hard law in order to become innovative in introducing new soft law instruments. This self-awareness makes the European Union's understanding of the ESM particular and reflexive. It reflects on the need for reform of the member states' welfare policies and understands its role as being a facilitator of their processes of self-transformation. The reflexive modernisation of welfare states is required in order to cope with the challenges that the risk society as well as globalisation pose..$^{42}$ In this context, the EU itself becomes reflexive by acting as the coordinator of the welfare states' self-transformation.

\section{Concluding Remarks}

Flexicurity forms a part of efforts to experiment with new forms of governance in the social and employment law of the European Union. It is compatible with attempts to introduce policies at the supranational level that can influence self-transformation processes at the level of the member states in order to reach overarching economic goals defined by the Lisbon agenda. It is central in the debate over the reform of labour law systems since it is a key, if not the key, concept in the 2006 Green Paper on modernising labour law in the European Union. ${ }^{43}$

\footnotetext{
42 See U. Beck: Risk Society: Towards a New Modernity, London 1992, Sage.

43 EU Commission: Green Paper on Modernising Labour law to Meet the Challenges of the 21st Century, COM(2006), 708 final.
}

Intereconomics, March/April 2008 
The debate and the policies pursued under the heading of flexicurity are shaped by, and at the same time influence, the discourse on new techniques of governance in the EU. The balancing of flexibility and security requires a fairly open-ended negotiation process. It is the process that matters and not particular policy goals. What is of importance from a regulatory point of view are the dynamics of the process and what makes it happen. Thus the main legal concern lies with procedure and not with content. This coincides with the new methods of governance pursued at the supranational level that focus on procedural aspects to influence the policies of the member states. Annual reports, monitoring, evaluation, benchmarking and peer review are soft legal instruments that are procedural and facilitative in nature. They are characterised by a reflexive understanding of the role of law as a mechanism of regulation that ultimately aims at supporting of self-regulation. ${ }^{44}$

Flexicurity as a concept fits well into the debate on a European Social Model. It gives guidance for welfare reform processes at the level of the member states who have to balance existing systems of welfare and employment rights and institutions with demands for new forms of employment. It is process-oriented and provides incentives for bargaining rather than imposing solutions. There is a danger, however, in the current debate at the EU level. Just as with the notion of the European Social Model, the flexicurity concept can lose its meaning and become empty and then be used in a superficial manner. Despite the Commission's efforts to translate the flexicurity concept into concrete polices through the identification of "common principles", it cannot be denied that there is a tendency in the current Barroso Commission to downplay social protection, to prioritise the economic Lisbon agenda, and to concentrate efforts on issues of transparency and the marketing of coordinated polices, instead of substantive discussions of policies. However, the success of coordination, including how flexicurity policies affect the welfare regimes of the member states, ultimately depends on the ability of European policies to become reflexive by adequately taking into account the needs and conditions of self-regulation in the member states themselves.

\footnotetext{
44 On the concept of reflexive labour law as regulation of self-regulation see R. Rogowski: The Concept of Reflexive Labour Law. Its Theoretical Background and Possible Applications, in: J. Priban, D. Nelken (eds.): Law's New Boundaries. The Consequences of Legal Autopoiesis, Aldershot 2001, Ashgate, pp. 179-196; and R. Rogowski, T. Wilthagen (eds.): Reflexive Labour Law. Studies in Industrial Relations and Employment Regulation, Deventer 1994, Kluwer.
}

Intereconomics, March/April 2008 


\section{Flexicurity: a Contested Concept at the Core of the European Labour Market Debate}

\begin{abstract}
In the past European integration has concentrated first of all on profound economic integration, creating the Single Market with common rules and regulations throughout the European Union. European integration has been more limited in the labour market and social field where the national state remains the dominant level of regulation. In the 1990s the European Employment Strategy (EES) emerged as an alternative, soft mode of governance to reduce the exclusive focus on economic integration. For two years, the European Commission has been promoting flexicurity as the new focus of the EES, pushing it to the top of the European employment policy agenda. Flexicurity is presented as the key to achieving full employment and as a means of combining economic and social objectives.
\end{abstract}

In the present paper the emergence of flexicurity in the Commission's employment policy discourse will be discussed, as well as the reaction of other European actors to the Commission's position. It will be argued that although the Commission presents flexicurity as a balanced approach which caters to the needs of both workers and employers, careful scrutiny of its position shows that its concept of flexicurity sets flexibility above security, economic goals above social ones and employers' interests above those of workers. A number of European stakeholders and observers reject the commission's position and, as a result, today flexicurity is a contested concept which is used by a variety of actors to promote their traditional views on labour market reforms.

\section{European Integration, the Labour Market and the European Employment Strategy}

Already more than a decade ago, Fritz Scharpf insightfully argued that European integration created a fundamental asymmetry between negative integration and positive integration.1 "Negative integration", i.e. measures that serve to increase market integration by eliminating national restraints on trade and distortions of competition, has been the dominant feature of Eu-

* Senior Researcher, European Trade Union Institute, Brussels, Belgium. ropean integration, while "positive integration", i.e. the development of common European policies to shape the conditions under which markets operate, has been much more limited. Negative integration has from the outset been at the core of the European Treaties, and member states have been irreversibly committed to European economic integration and the deepening of the internal market. They have been prepared to transfer much of their sovereignty in this field to the European level and, as a result, a comprehensive apparatus of European-level economic directives, regulations and policies is in place that institutionalises market coordination and fosters competition.

Positive integration has been a much more complicated matter, especially where the labour market is concerned. The Treaty of Rome (1957) left social policy and labour market regulations basically to the member states. Initially, the competences of the Community in the social field were oriented towards facilitating the building of the market. As such, they were largely limited to the free movement of workers, equal treatment and equal pay. Over time the competencies of the Community in the social and labour market areas were gradually expanded to other areas, especially health and safety, following a proactive role of the European Commission and creative rulings by the European Court of Justice (ECJ). At the same time, however, in the 1992 Maastricht Treaty, some issues, most importantly wages, the right to strike and the right of association, were explicitly singled out as falling outside Community competence. What is more, the Treaty introduced the principles of subsidiarity and proportionality, thus formally recognising and respecting national diversity in relation to social issues. As a result, the development of European regulations in the social and labour market areas has been very limited. Regulation is fragmentary, largely complementary to national regulations, and fails to make up a coherent

${ }^{1} \mathrm{~F}$. Scharpf: Negative and positive integration in the political economy of European welfare states, in: G. Marks, F. Scharpf, P. Schmitter, W. Streeck (eds.): Governance in the European Union, London, 1996, SAGE Publications; F. Sch arpf: The European social model: coping with the challenges of diversity, in: Journal of Common Market Studies, Vol. 40, No. 4, 2002, pp. 645-670. 
or comprehensive social or labour market model. ${ }^{2}$ This is in stark contrast with the deep and comprehensive economic integration that has dominated European integration.

The limited advancement of European integration in the labour market field is due to a number of reasons. Hooghe and Marks ${ }^{3}$ picture European politics as an interplay between two political projects, i.e. between (i) the neoliberal project pursuing European-wide market integration while at the same time trying to insulate the market from political interference; and (ii) the regulated capitalism project which wants market integration to be accompanied by positive market enhancing and market-supporting regulations to create a social democratic dimension to European governance. The coalition of actors supporting the regulated capitalism project, including social-democratic parties, a number of Christian-democratic parties, national and European trade unions, as well as certain sections of the European Commission, has made many attempts to extend European social and labour market regulations but with only limited success. The neo-liberal coalition, comprising, among others, liberal parties, many conservative parties, financial interests, multinationals and national and European employers' organisations, has been more powerful in past decades and has successfully been able to block most attempts at positive integration. $^{4}$

Negative integration also has been strongly institutionalised in the European Treaties from the outset and has been extended consistently by interventions of the European Commission against Treaty obligations and through rulings by the ECJ. ${ }^{5}$ Positive integration, by contrast, depends upon the agreement of national governments in the Council and is subject to a series of impediments facing European intergovernmental decision-making. ${ }^{6}$ This is particularly so since in many areas related to positive integration decisions are based upon unanimity. Hence, in institutional terms,

\footnotetext{
2 J. Goetschy: Taking stock of social Europe: Is there such a thing as a Community social model?, in: M. Jepsen, A. Serrano Pas cual (eds.): Unwrapping the European Social Model, Bristol 2006, Policy Press; M. Keune: EU Enlargement and Social Standards: Exporting the European Social Model?, in: J. Orbie, L. Tortell (eds.) The EU and the Social Dimension of Globalisation, GARNET 'Europe in the World' series, London and New York, forthcoming, Routledge.

3 L. Hooghe, G. Marks: The Making of A Polity. The Struggle over European Integration, in: H. Kitschelt, G. Marks, P. Lange, J. Stephens (eds.): Continuity and Change in Contemporary Capitalism, Cambridge 1999, Cambridge University Press.

4 Ibid.

5 F. Scharpf: Negative and positive intgration ..., op. cit., p. 15. 6 Ibid.
}

Intereconomics, March/April 2008 negative integration faces fewer obstacles than positive integration.

Moreover, an important role is played by the heterogeneity of European countries in terms of their institutional characteristics, traditions and interests, in particular concerning their welfare states, industrial relations systems, labour market regulation and other areas of positive regulation. This heterogeneity has spurred strong desires to preserve national sovereignty on these issues and has made it hard to reach an agreement on elements of positive integration. ${ }^{7}$ Heterogeneity has increased dramatically with the 2004 and 2007 rounds of European enlargement, which substantially increased both the number of member states and the extent of diversity, further complicating the development of positive integration. ${ }^{8}$

Within the context of predominantly negative European integration, combined with widespread unemployment throughout the 1990s and great uncertainty as to how to deal with this problem, the European Employment Strategy (EES) emerged. In the eyes of the proponents of regulated capitalism as well as in the eyes of much of the public the lack of European attention to unemployment contrasted more and more with the EU's drive for further economic integration, including moves towards monetary union. As a result, a coalition committed to a more active role for the EU in employment policy consolidated itself in the mid-1990s, consisting of key actors within the Commission, the European Parliament, and member state governments, especially recently acceded countries such as Sweden but also newly elected centre-left governments like the Blair government in the UK and the Jospin government in France. ${ }^{9}$ Their pressure resulted in the inclusion of an employment chapter in the 1997 Amsterdam Treaty and in an extraordinary European Council meeting on employment (the "Jobs Summit") in Luxembourg in that same year the EES was launched.

The EES as a new, soft type of governance does not impose specific rules and regulations at national level. Instead, the European Council monitors national policies. It adopts a series of common objectives,

\footnotetext{
7 Ibid.; F. Scharpf: The European social model ..., op. cit.

8 M. Keune: The European model and enlargement, in: M. J e ps en, A. Serrano Pascual (eds.), op. cit.

9 J. Zeitlin: A Decade of Innovation in EU Governance: The European Employment Strategy, the Open Method of Coordination, and the Lisbon Strategy, Paper prepared for the Portuguese Presidency of the European Union, June 2007; M. Mailand: Coalitions and Policy Coordination - Revision and Impact of the European Employment Strategy, Copenhagen 2006, DJØF Forlagene.
} 
guidelines and indicators for monitoring, based upon proposals from the Commission. The Council's competencies include the possibility of specific recommendations towards individual member states. The member states each have to develop their National Action Plans for Employment (NAPs), outlining how the general guidelines will be put into practice. Hence, actual policy decisions are left to national authorities and adaptation to the EES guidelines is voluntary. To a large extent the EES is based on the Open Method of Coordination (OMC). The OMC aims to strike a balance between European integration and deep-rooted and legitimate national diversity by encouraging the convergence of objectives, performance and broad policy approaches, but not of specific programmes, rules or institutions. ${ }^{10}$ Additionally, the OMC aspires to promote learning and benchmarking as well as the incorporation of a broad range of actors in its processes. Moreover, the Commission regards the EES as a means of framing and structuring the debate on employment policies in Europe by disseminating cognitive models and concepts, comparing the performance in the different member states and identifying "best practices". ${ }^{11}$ Also, it actively tries to shape and reshape the EES over time.

\section{The Emergence of Flexicurity}

The term flexicurity was first employed in the mid1990s in the Netherlands, in the context of the preparation of the Dutch Flexibility and Security Act and the Act concerning the Allocation of Workers via Interme-

$10 \mathrm{~J}$. Zeitlin: The Open Method of Coordination in Action. Theoretical Promise, Empirical Realities, Reform Strategies, in: J. Zeitlin, P. Pochet, L. Magnusson (eds.): The Open Method of Coordination in Action: The European Employment and Social Inclusion Strategies, Brussels 2005, Peter Lang, p. 448.

11 M. Keune, M. Jepsen: Not balanced and hardly new. The European Commission's quest for flexicurity, in: H. Jørgensen, P. K. Madsen (eds.): Flexicurity and Beyond, Copenhagen 2007, DJøF Publishing; There is little agreement in the literature concerning the extent to which the EES is achieving its objectives and concerning its actual influence on national policies and policymaking processes. There seems to be agreement on the powerful position of the Commission as agenda setter and disseminator of cognitive models and concepts. The direct influence on national policymaking is much more disputed. For general discussions of the EES, see e.g. M. Mailand, op. cit.; A. Watt: Reform of the European Employment Strategy after five years: a change of course or merely of presentation?, in: European Journal of Industrial Relations, Vol. 10, No. 2, 2004, pp. 117-137; B. Cas ey: The OECD Jobs Strategy and the European Employment Strategy: Two Views of the Labour Market and the Welfare State, in: European Journal of Industrial Relations, Vol. 10, No. 3, 2004, pp. 329-352. More specifically on the OMC employment, see J. Zeitlin, P. Pochet, L. Magnusson (eds.), op. cit.; A. Schüttpelz: Policy Transfer and pre-accession Europeanization of the Czech employment policy, Discussion paper SP III 2004-2001, Berlin 2004, WZB; K. $\mathrm{J}$ a c obs s on: Soft regulation and the subtle transformation of states: the case of EU employment policy, in: Journal of European Social Policy, Vol. 14, No. 4, 2004, pp. 355-370; J. Zeitlin: A Decade of Innovation ..., op. cit. diaries. ${ }^{12}$ Dutch flexicurity promotes the use of atypical, flexible types of employment which are subject to similar rights concerning working conditions and social security as standard employment. In subsequent years, attention shifted to Denmark as an alternative flexicurity model to the Dutch one. The Danish flexicurity model, rather than being concerned with atypical types of employment, builds on

- flexible standard employment, resulting from low dismissal protection;

- extensive unemployment benefits providing income security to the unemployed;

- active labour market policies aimed at skill upgrading and activation of the unemployed..$^{13}$

These two national cases have aroused interest in flexicurity on the part of both the academic community and politicians and policymakers, among other things because both countries have managed to improve their labour market situation remarkably since the mid-1990s, reducing unemployment rates to the lowest and employment rates to the highest levels in Europe. ${ }^{14}$

Another reason for this growing interest in flexicurity is that it constitutes an alternative to the (largely bankrupt) neo-liberal view of the labour market which dominated the debate during much of the 1980s and

12 T. Wilthagen, F. Tros: The concept of "flexicurity": A new approach to regulating employment and labour markets, in: Transfer, Vol. 10, No. 2, 2004, pp.166-186; W. Van Oors chot: Flexible work and flexicurity policies in the Netherlands. Trends and Experiences, in: Transfer, Vol. 10, No. 2, 2004, pp. 208-225.

13 P. Madsen: The Danish model of flexicurity: A paradise - with some snakes, in: Hedva Sarfati, Giuliano Bonoli (eds.): Labour market and social protection reforms in international perspective: Parallel or converging tracks? Aldershot 2002, Ashgate, pp. 243-265.

14 It is questionable, though, to what extent the flexicurity models of the two countries have led to successful labour market developments. Dutch employment and unemployment rates are favourable largely because of a high share of part-time employment (now close to $50 \%$ ): when calculated in full-time equivalents the Dutch employment rate is actually similar to the German rate and below that of countries like Spain, France or Greece (WRR: Investeren in Werkzekerheid, Wetenschappelijke Raad voor het Regeringsbeleid rapport No. 77, Amsterdam 2007, Amsterdam University Press. Table 2.2). And in the Danish case the importance of the country's flexicurity model seems overrated. Indeed, it is inevitably an over-simplistic undertaking to seek to explain labour market success or failure solely by the type of labour market regulations. More complex approaches, taking into account elements like macroeconomic conditions, wage policies, fiscal policies, industrial relations systems, are required. For examples of such more complex explanations of the Danish success and revival since the mid-1990s, see J. Campbell, J. Hall, O. Pedersen (eds.): National identity and the varieties of capitalism: the Danish experience, in: Montreal \& Kingston, London, Ithaca 2006, McGill-Queen's University Press; C. Larsen: Policy paradigms and cross-national policy (mis)learning from the Danish employment miracle, in: Journal of European Public Policy, Vol. 9, No. 5, October 2002, pp. 715-735. 
1990s. ${ }^{15}$ By the end of the 1990s, the fallacy of this view had become only too apparent and the OECD retracted many aspects of its radical stance; in particular, it now accepts that there is no clear relation between the level of employment protection in a country and its level of unemployment. ${ }^{16}$ Indeed, today the OECD also hails the success of the Dutch and Danish labour markets and refers positively to the Danish flexicurity approach.

Today flexicurity is the subject of numerous academic publications and is at the core of the political debate about labour market reform. This makes it all the more peculiar that the concept remains quite ill-defined and ambiguous. Possibly the best-known definition comes from Wilthagen and Tros who see flexicurity as "... a policy strategy that attempts, synchronically and in a deliberate way, to enhance the flexibility of labour markets, work organisation and labour relations on the one hand, and to enhance security - employment and social security - notably for weaker groups in and outside the labour market, on the other hand". ${ }^{17}$ This definition leaves a lot of scope for interpretation. For example, it does not prioritise different types of flexibility over others or specify how much flexibility or security is adequate. Hence, this definition can in principle cover a broad range of labour market models or reforms. In addition, others employ quite different definitions. For example, for Auer ${ }^{18}$ flexicurity basically refers to protected mobility, while for many, flexicurity has become a synonym for the Danish labour market model. What is more, the flexicurity models of two countries seen as the key flexicurity cases, i.e. the Netherlands and Denmark, have little in common.

\section{The European Commission and its Flexicurity Strategy}

Possibly the main reason why flexicurity has become such a key concept has been its wholehearted adoption by the European Commission. In the past two years, the Commission has organised a large number of summits, conferences and seminars on flexicurity. Furthermore, the Commission's 2006 and 2007 Employment in Europe Reports devote a major

\footnotetext{
15 OECD: The OECD Jobs Study, Organisation for Economic Co-operation and Development, Paris 1994.

16 OECD: OECD Employment Outlook. Boosting jobs and income, Organisation dor Economic Co-operation and Developmant, Paris 2006, pp. 96-100; OECD: OECD Employment Outlook, Organisation for Economic Co-operation and Development, Paris 1999.

17 T. Wilthagen, F. Tros, op. cit., p. 169.

18 P. Auer: Protected mobility for employment and decent work: labour market security in a globalised world, in: Employment Strategy Papers, No. 1, 2005, ILO, Geneva.
}

part of their analysis to flexicurity. ${ }^{19}$ Flexicurity is also at the heart of the Commission's Green Paper on labour law, which "... looks at the role labour law might play in advancing a 'flexicurity' agenda". ${ }^{20}$ Moreover, in June 2007 the Commission published its flexicurity communication, ${ }^{21}$ representing its most comprehensive effort to outline its view, including a set of "common flexicurity principles" which were proposed to the Council for adoption. Finally, flexicurity has become the core concept in the employment guidelines of the European Employment Strategy (EES) proposed by the Commission for 2008-2010. ${ }^{22}$

The Commission forwards flexicurity as an innovative concept for labour market reform and defines it, following Wilthagen and Tros, as an integrated strategy to enhance, at the same time, flexibility and security in the labour market. It argues flexicurity is a means of combining economic and social objectives which holds benefits for both workers and employers and reconciles their interests. The rationale for flexicurity is argued to be, first of all, the need to increase the

19 CEC: Employment in Europe 2006, Office for Official Publications of the European Communities, Luxembourg 2006; CEC: Employment in Europe 2007, Office for Official Publications of the European Communities, Luxembourg 2007.

20 CEC: Green Paper. Modernising labour law to meet the challenges of the 21st century, COM (2006) 708 of 22 November 2006 , p. 4, http://ec.europa.eu/employment_social/labour_law/docs/2006/ green_paper_en.pdf.

21 CEC: Communication from the Commission to the Council, the European Parliament, the European Economic and Social Committee and the Committee of the Regions 'Towards Common Principles of Flexicurity: more and better jobs through flexibility and security', COM (2007) 359 of 27 June 2007, http://ec.europa.eu/employment_social/ news/2007/jun/flexicurity_en.pdf/.

22 CEC: Integrated guidelines for growth and jobs (2008-2010) including a Commission recommendation on the broad guidelines for the economic policies of the Member States and the Community (under Article 99 of the EC Treaty) and a proposal for a Council decision on guidelines for the employment policies of the Member States (under Article 128 of the EC Treaty), Brussels 2007, http://ec.europa.eu/ growthandjobs/pdf/european-dimension-200712-annual-progressreport/200712-annual-report-integrated-guidelines_en.pdf; The attention paid to the relation between flexibility and security is, however not a novelty in the EES. In the first employment guidelines of 1998 , the social partners were already invited to negotiate agreements to modernise the organisation of work with the aim of making undertakings productive and competitive and achieving the required balance between flexibility and security. Also, in the 2003 guidelines it was argued that the right balance between flexibility and security will help support the competitiveness of firms, increase quality and productivity at work and facilitate the adaptation of firms and workers to economic change. Cf. Council of the European Union: Council Decision of 22 July 2003 on guidelines for the employment policies of the Member States, OJ L 197 of 5 August 2003, pp.13-21, http://europa.eu/eurlex/pri/en/oj/dat/2003/I_197//_19720030805en00130021.pdf. Finally, in the 2005 guidelines, guideline 21 called upon the member states to promote flexibility combined with employment security and reduce labour market segmentation, having due regard to the role of the social partners. Cf. Council of the European Union: Council Decision of 12 July 2005 on Guidelines for the employment policies of the member states, OJ L 205 of 6 August 2005, pp. 21-27, http://eur-lex.europa. eu/LexUriServ/site/en/oj/2005//_205/I_20520050806en00210027.pdf. 
adaptability of enterprises and workers to the changes in the global economy. For companies this means they "... need to be able to adapt their workforce to changes in economic conditions. They should be able to recruit staff with a better skills match, who will be more productive and adaptable leading to greater innovation and competitiveness". ${ }^{23}$ For individuals, it is argued that they "... increasingly need employment security rather than job security, as fewer have the same job for life". ${ }^{24}$ Employment security is then defined as the possibility of finding a job at every stage of active life in a quickly changing economic environment, which includes more frequent transitions between jobs and between different labour market states. A second rationale for flexicurity is argued to be the need to reduce labour market segmentation between well-protected insiders and marginalised outsiders.

The Commission's flexicurity approach has four components:

- flexible and reliable contractual arrangements through modern labour laws, collective agreements and work organisation;

- comprehensive life-long learning strategies;

- effective active labour market policies that help people cope with rapid change, reduce unemployment spells and ease transitions to new jobs;

- modern social security systems that provide adequate income support, encourage employment and facilitate labour market mobility.

In addition, the Commission argues that the involvement of the social partners in designing flexicurity policies is crucial for their success. It also underlines that flexicurity is not about one single model but that it should be shaped according to particular national situations.

In this way, the Commission's flexicurity discourse neatly fits the EES approach of striking a balance between European integration and national diversity: it maintains to encourage convergence of objectives, performance and broad policy approaches, but not of specific policy programmes. It is also presented as an inclusive approach fostering win-win situations in which all benefit. Moreover, it matches the broader Commission discourse on the European Social Model, which also emphasises the combination of economic

\footnotetext{
${ }^{23}$ CEC: Communication from the Commission..., op. cit., p. 4. 24 Ibid.
}

and social objectives. ${ }^{25}$ From this perspective, flexicurity is, apart from a strategy to strengthen labour market efficiency, also an attempt to reaffirm the social dimension of European integration, not through hard regulations which face too many political and institutional obstacles, but through soft regulations. This is today all the more important since the continued dominance of negative integration seems to lead to a growing alienation and contestation concerning "Europe", the most vivid manifestations of this phenomenon being the French "non" and Dutch "nee" to the European constitution.

However, a more detailed examination of recent Commission documents and employment policy recommendations shows that the Commission argues for increased flexibility through low levels of dismissal protection as well as the normalisation of non-standard contracts, while security is largely limited to employment security, to be fostered through life-long learning and active labour market policies. ${ }^{26}$ Where modern social security systems are concerned, the Commission remains vague and ambiguous, arguing that good unemployment benefit systems are necessary to offset negative income consequences during job transfers; but at the same time arguing that unemployment benefits may have a negative effect on the intensity of job search activities and may reduce the financial incentives to accept work.

This picture is further confirmed by the Commission's proposal for recommendations to member states on economic and employment policies. ${ }^{27}$ Where dismissal protection and flexible contracts are concerned, the Commission advises a number of countries to review employment protection legislation with a view to reducing labour market segmentation (i.e. to reduce employment protection) and increasing the use of flexible contracts. However, in no country does it recommend an increase in employment protection, suggesting that even in the countries in which it is lowest its level remains adequate. For example, even in

\footnotetext{
25 M. Jepsen, A. Serrano Pascual: Deconstructing the European Social Model, in: M. Jepsen, A. Serrano Pascual (eds.), op. cit.

26 For a detailed analysis see M. Keune: Flexicurity: the new cure for Europe's labour market problems?, in: C. Degryse, P. Pochet (eds.): Social Developments in the European Union 2007, Brussels 2008, ETUI-REHS/OSE; M. Ke une, M. J ep s en, op. cit.

27 CEC: Recommendation for a Council Recommendation on the 2008 up-date of the broad guidelines for the economic policies of the Member States and the Community and on the implementation of Member States' employment policies, Brussels, 11 December 2007, http://ec.europa.eu/growthandjobs/pdf/european-dimension200712-annual-progress-report/200712-countries-specific-recommendations_en.pdf.
} 
Estonia, known for a very flexible labour market, the Commission recommends reducing labour market rigidities by means of urgent progress towards labour law modernisation and by promoting flexible forms of work. $^{28}$

For most countries the document recommends a strengthening of activation policies, active labour market policies and life-long learning. This clearly underscores the focus on employment security. The case of unemployment benefits is different. Although in its more general statements like the Communication discussed above the Commission calls for adequate unemployment benefits, in its country recommendations there is not one case in which it calls for the improvement of those benefits, even though in a number of countries they are clearly very minimal in terms of replacement rates, coverage or duration. The document does in some cases call for a review of benefits to improve incentives to work (e.g. Poland), or for a tightening of the conditions for early retirement (e.g. Austria).

Hence, although flexicurity is presented as a balanced approach designed to create the flexibility needed by employers while at the same time providing security to workers, careful scrutiny of the Commission's position shows that its concept of flexicurity sets flexibility above security, economic goals above social ones and employers' interests above those of workers. In this way, it represents negative rather than positive integration and is closer to the goals of the neoliberal capitalism project than those of the regulated capitalism project. It also marks a shift in the Commission's thinking on heterogeneity: whereas previously it focused on supply-side problems and took national diversity as a given, it now identifies longestablished national institutions such as dismissal protection and standard contracts as obstacles to the proper functioning of the labour market. In this way, along the lines argued by Höpner and Schäfer, ${ }^{29}$ the Commission is now seeking to achieve convergence towards market capitalism by targeting some of the key labour market institutions of regulated capitalism.

\section{Flexicurity: a Contested Concept}

The European Commission has undoubtedly been successful in setting the agenda where flexicurity is concerned. Flexicurity is at the heart of today's European labour market debate and it is widely accepted

\footnotetext{
28 Ibid.

${ }_{29}$ M. Höpner, A. Schäfer: A New Phase of European Integration. Organized Capitalisms in Post-Ricardian Europe, MPIfG Discussion Paper 07/4, Cologne 2007, Max-Planck-Institut für Gesellschaftsforschung.
}

Intereconomics, March/April 2008 to be an issue of key importance. Nevertheless, the inherent ambiguity of the concept as well as the particular content given to it by the Commission have also made it a contested concept. Indeed, the way the concept is used and translated into policy by different European actors differs substantially.

As to the Council, it adopted a document with eight flexicurity principles aimed at framing national reforms. ${ }^{30}$ The Council's principles are fairly similar to those proposed by the Commission and represent an over-generalised summary of the Commission's flexicurity discourse but do not include any concrete commitment. Importantly, though, the Council's principles are indeed not identical to those proposed by the Commission. The major difference is that the Council has included a statement which contradicts the Commission's drive for flexibility, in particular in terms of contracts and employment protection: "The inactive, the unemployed, those in undeclared work, in unstable employment, or at the margins of the labour market need to be provided with better opportunities, economic incentives and supportive measures for easier access to work or stepping-stones to assist progress into stable and legally secure employment" ${ }^{31}$ This represents a clear departure from the Commission's view on the need for limited dismissal protection and from its acceptance of flexible contracts, and gives more space to national diversity. This is further underlined by the emphasis the member states placed earlier on standard rather than atypical employment relationships: "The member states are called upon to strengthen standard working relationships in accordance with their national practice and to limit their circumvention by atypical employment relationships."

The European Parliament, in its opinion on the Commission's Communication, also takes a number of positions that contradict the Commission. ${ }^{32}$ The Parliament strongly states that the view of the Commission is one-sided and too focused on flexibility. It argues for simultaneously improving employment security and job security and for maintaining the traditional model of open-ended contracts. One of the reasons it gives for this view, in line with the regulated capitalism approach, is the fact that job protection and longer-term employment relationships act as incentives for firms to invest in human resources, which in turn is good for

\footnotetext{
30 Council of the European Union: Council conclusions. Towards Common Principles of Flexicurity, adopted on 5/6 December 2007.

31 Ibid., p. 5, emphasis added.

32 European Parliament: Report on common principles of flexicurity 2007/2209(INI), Committee on Employment and Social Affairs, Brussels $2007,15.11 .2007$.
} 
productivity and innovation. ${ }^{33}$ Flexibility, then, should be achieved through raising education, expanding training and apprenticeship programmes, policies against discrimination, removing obstacles to mobility, and policies supporting transitions. ${ }^{34}$ Finally, the European Parliament argues that flexicurity requires a macroeconomic framework that supports job creation.

The position of BusinessEurope, the largest European employers' organisation, is close to that of the Commission. BusinessEurope argues that, "In today's labour market, security is not so much a matter of preserving a job for life. Instead, it is about making sure that workers are empowered to grasp new employment opportunities. Flexicurity is the key instrument to support companies' and workers' efforts to adapt to change and to move from a job preservation mindset to a job creation mindset, which is in turn crucial to achieve lower levels of social exclusion in Europe." 35 In the employer's view, flexicurity should consist of flexible labour law and a variety of contracts; active labour market policies and life-long learning; and unemployment benefit systems that reduce unemployment periods to a minimum. ${ }^{36}$

The European Trade Union Confederation (ETUC) reasons differently. It argues that business in Europe already enjoys high adaptability, that the European economy is already flexible and that job creation has the upper hand over job destruction. ${ }^{37}$ Rather, the ETUC identifies the prevalence of precarious employment and excessive flexibility as key problems and puts forward the improvement of the quality of jobs as a key objective. Like the European Parliament, it argues for employment security as a complement, rather than an alternative, to job security, for open-ended contracts as the general rule and for upgrading the rights of atypical workers. Where labour market policies are concerned, the ETUC argues for a high level of benefits combined with active labour market policies as well as for including groups presently not covered by social security schemes. ${ }^{38}$ High benefits and active labour market policies, it maintains, provide

\footnotetext{
33 Ibid.

34 Ibid.

35 BusinessEurope: Europe's social reality: a stocktaking, BusinessEurope Position Paper, 2008, http://www.businesseurope.eu/Content/ Default.asp

36 Intervention by Mr. Philippe De Buck, BusinessEurope Secretary General at the Commission Stakeholder Conference on Flexicurity, 20 April 2007.

37 ETUC: The Flexicurity debate and the Challenges for the Trade Union Movement, Brussels 2007, ETUC.

38 Ibid.
}

security as well as being positively associated with labour market participation. Finally, the ETUC argues for the integration of flexicurity policy with macroeconomic policies oriented towards growth and employment creation, given that flexicurity by itself does not have employment-creating capacities.

From the above examples it can be seen that there is no European consensus on flexicurity. The ambiguous nature of the flexicurity concept makes it possible for everyone to subscribe to its importance. At the same time, different actors have quite different understandings of the concept as such, as well as of its policy implications, much along the lines of the neoliberal capitalism vs. regulated capitalism divide. The concept is widely open to interpretation and different actors put forward quite different versions of flexicurity, using it as a banner to promote their traditional views on labour market reforms.

\section{Conclusions}

European integration has predominantly been a process of negative integration, largely fostering market coordination, while positive integration constraining the market and mitigating its negative social effects has been very limited. In recent years, the European Commission has forwarded flexicurity as a new and balanced approach to improving the performance of the European labour market, to combining economic and social objectives and to addressing the needs of both workers and employers. Careful scrutiny of its position shows, however, that its concept of flexicurity sets flexibility above security, economic goals above social ones and employers' interests above those of workers. As a result, the Commission's position has become a contested one that is rejected by a number of other European actors. What is more, flexicurity continues to be ill-defined and ambiguous, which allows different actors to use it to promote their diverging views on labour market reforms. Indeed, flexicurity debates often continue to be about what it is exactly rather than about its usefulness.

As with all soft regulation, it remains to be seen what effect the European-level flexicurity debate will have at the national level. Although the concept is being used more and more in national debates, it has not lost any of its vagueness and ambiguity. Hence, it seems unlikely that flexicurity will become the consensual motor of innovative national employment policy in the years to come. 


\section{Is Europe Ready for Flexicurity? Empirical Evidence, Critical Remarks and a Reform Proposal}

$\mathrm{R}_{\mathrm{in}}^{\mathrm{e}}$ ecently, the European Commission ${ }^{1}$ issued two important documents with arguments in favour of the "flexicurity" approach to labour market reforms. Flexicurity is explained as a policy which makes the flexibilisation (= deregulation) of labour markets aimed at fostering the competitiveness of European economy compatible with the European tradition of the welfare state. For this purpose, flexibilisation should be compensated for by improvements in social security and employment security, constituting a kind of trade-off.

According to the concept of flexicurity, flexibilisation should improve firms' performance, which in turn should foster production and stimulate labour markets, creating "more and better jobs", as declared at the EU Lisbon summit in 2000. The "better jobs" correspond to the ILO ${ }^{2}$ concept of decent work, combining promotion of rights at work, employment, social protection and social dialogue, with employability playing a central role. To make the idea of decent work clearer, the ILO contrasts it with precarious work, which is characterised by lower income, lower employment stability, lower employability and lower integration into social security schemata. ${ }^{3}$

The European Commission puts forward employability as the keystone of the European Employment Strategy and, thus, flexicurity. As emphasised in Employment in Europe 2006 by the European Commission:4 "The main thrust of the EU recommendation on flexicurity is to encourage a shift ... towards employment security ... In particular, investing in human capital is vital both to improve the long-term employment prospects and the employment security of the individual, and also to enhance the competitiveness and adaptability of the labour force." In turn, employment security is "to provide people with the training they need to keep their skills up-to-date and to develop their talent". ${ }^{5}$

Previous empirical reports by the Hans Böckler Foundation have shown that current European policy has failed to compensate for the ongoing deregulation

* Hans Böckler Foundation, Düsseldorf, Germany. of the labour market with social security advantages. ${ }^{6}$ In other words, the first flexicurity nexus "flexibilitysocial security" does not work. Now European policymakers are putting forward the second flexicurity nexus "flexibility-employment security". The compensation is hoped to be attained through a higher employability due to life-long learning, and in particular, company-based training. It is expected to improve the mobility of the labour force, implying stable employment and broad opportunities to move into better jobs.

Therefore, the consistency of the flexicurity concept is linked to the impact of flexibilisation on the decentness-precariousness of work. According to the flexicurity concept, flexible work should in no case be precarious and imply a lower employability; on the contrary, employability should increase to compensate for the negative effects of flexibilisation. The second crucial point of the Commission's flexicurity concept is the wide availability of professional training options and the readiness of Europeans to learn.

It is the aim of the present paper to test empirically these conditions which form the basis for the Euro-

1 European Commission: Green Paper: Modernising labour law to meet the challenges of the 21st century, Brussels 22.11.2006, COM (2006) 708 final, http://ec.europa.eu/employment_social/labour_law/ docs/2006/green paper en.pdf; European Commission: Towards Common Principles of Flexicurity: More and Better Jobs Through Flexibility and Security, Brussels 2007

2 ILO: Report of the Director-General: Decent Work. International Labour Organisation, Geneva 1999, http://www.ilo.org/public/english/ standards/relm/ilc/ilc87/rep-i.htm.

${ }^{3}$ For details see B. Keller, H. Seifert: Atypische Beschäftigungsverhältnisse: Flexibilität, soziale Sicherheit und Prekarität, in: WS Mitteilungen, No. 5, 2006, pp. 235-240; H. Seifert, A. Tangian: Reconciling social security with flexibility - empirical findings for Europe, Diskussionspapier 154, Hans Böckler Stiftung, Düsseldorf 2007, http://www.boeckler.de/pdf/p_wsi_diskp_154_e.pdf.

${ }^{4}$ European Commission: Employment in Europe 2006, European Communities, Luxembourg 2006, p. 78

${ }^{5}$ European Commission: Towards Common Principles ..., op. cit, p. 11

${ }^{6}$ A. Tangian: Monitoring flexicurity policies in the EU with dedicated composite indicators, WSI Diskussionspapier 137, Hans Böckler Stiftung, Düsseldorf 2005, http://www.boeckler.de/pdf/p wsi diskp 137. pdf; A. Tangian: European flexicurity: concepts (operational definitions), methodology (monitoring instruments), and policies (consistent implementations), WSI Diskussionspapier 148, Hans Böckler Stiftung Düsseldorf 2006, http://www.boeckler.de/pdf/p wsi diskp_148 e.pdf; A. Tangian: European flexicurity: concepts, methodology and policies, in: Transfer, No. 4, 2007, pp. 551-573. 
Table 1

Data Structure for Constructing Composite Indicators of Flexibility and Precariousness of Work



Note: Question marks "?" show the aggregation of composite indicators.

pean flexicurity reforms. It starts by defining and operationalising flexibility and precariousness of work. The next step describes the model for processing data stemming from the Fourth European Working Conditions Survey 2005 by the European Foundation. ${ }^{7}$ To construct the indices of flexibility and precariousness in 31 European countries, two methodologies, differing in the scaling of variables, are applied. The first was developed by the Hans Böckler Foundation (HBS). ${ }^{8}$ The second comes from the OECD. ${ }^{9}$ The empirical analysis using both methodologies reveals (1) that the indices of flexibility and precariousness of work are correlated with statistical certainty, meaning that flexibility has a "wrong" effect, and (2) that flexibility has a significant negative impact on employability, contrary to the Commission's arguments.

In the second part of the paper, a composite indicator is constructed for quality of work. Its sub-indicators reflect the 15 aspects of working conditions described in the index recently published by the Confederation of German Trade Unions (DGB). ${ }^{10}$ In a sense, the German indicator is extended to European data. It reveals that (3) there is an acute shortage of learning options, i.e. Europe is not really prepared to offer the qualification facilities required; (4) learning makes a negative impact on job satisfaction, meaning there is a latent resistance to learning; and (5) job stability is ranked

${ }^{7}$ European Foundation: 4th European Working Conditions Survey, European Foundation for the Improvement of Living and Working Conditions, Dublin 2007, http://www.eurofound.europa.eu/publications/htmlfiles/ef0698.htm.

${ }^{8}$ Cf. A. Tangian: Monitoring flexicurity ..., op. cit; A. Tangian: Analysis of the third European survey on working conditions with composite indicators, in: European Journal of Operational Research, Vol. 181, 2007, pp. 468-499.

9 OECD: Handbook on Constructing Composite Indicators: Methodology and User Guide, 2005, http://www.olis.oecd.org/olis/2005doc. nsf/LinkTo/std-doc(2005)3.

10 DGB: DGB Index Gute Arbeit, in: Der Report, Berlin 2007, http:// www.dgb-index-gute-arbeit.de. first for job satisfaction, but income is ranked only 6th, in contrast to the Commission's claims that "individuals increasingly need employment security rather than job security" and that "there must be ... more upward mobility". ${ }^{11}$

All of this definitively disproves the belief that the flexibilisation of labour relations can be compensated for by high employability based on learning. It even turns out that flexibilisation and employability are even little compatible with each other. The shift from job security to employment security suggested by the European Commission cannot be consistently implemented. Our study provides empirical evidence that high employability can hardly be attained under flexible employment. Besides, Europe is not ready for life-long learning, with Europeans unambiguously preferring "just jobs" to "better jobs".

Therefore, an alternative concept of flexicurity has to be developed. The paper proposes the implementation of flexicurity in the form of flexinsurance, which implies that the employer's contribution to social security should be proportional to the flexibility (precariousness) of the contract. In order to stimulate employers to equalise the working conditions, of normal and atypical employees, it is proposed to introduce a workplace tax for bad working conditions which should protect "the working environment" in the same way as the green tax protects the natural environment.

\section{Operationalisation}

The data structure for the first part of the study is shown in Table 1, where each row consists of the answers of an individual to 42 questions: 29 on flexibility, and 13 on precariousness of work. The selection of questions shows how the notions of flexibility and precariousness of work are operationally defined in our study. The answers of each individual are aggregated

${ }^{11}$ European Commission: Towards Common Principles ..., op. cit, p. 8. Intereconomics, March/April 2008 
into individual indices of degree of flexibility and degree of precariousness of his/her work, which are put in the right-hand columns of the table. The questions are grouped into three sections.

Classifiers. This section includes the "demographic" questions on the country of interview, age and sex of the respondent etc. These data are not used in constructing the individual indices but are necessary to build social groups for comparative analysis. For instance, we use the country classifier (the variable "countcod") to compute the national averages of individual indices.

Flexibility. This section includes the questions on flexibility of work grouped according to the OECD ${ }^{12}$ classification of flexibility types.

1. External numerical flexibility, i.e. the ease of "hiring and firing", which manifests itself in the mobility of workers between employers (external job turnover). This type of flexibility is reflected by the survey variables linked to the following questions:

- type of contract (variable q3b): indefinite contract, fixed term contract, temporary agency work contract, or work with no contract

- duration of contract, in months (q3c).

2. Internal numerical flexibility, i.e. variability of standard number and standard distribution of working hours. The relevant survey questions are:

- number of working hours per week (derivative from variables q15a and q15b): corresponding to individual's wishes or not

- overtime (more than 10 hours per day), in number of times a month (q14e)

- number of working hours per day (q16aa): variable or constant

- number of working days per week (q16ab): variable or constant

- starting and finishing hours (q16ac): variable or constant

- working time arrangements (q17a): set by the company, choice of several options, reasonable adaptability to individual wishes, or full adaptability

- working time planning (q17b): on the same day, the day before, several days in advance, several weeks in advance, no changes of schedule.

${ }_{12}$ OECD: Labour Market Flexibility, Trends in Enterprises, Paris 1989 , OECD, pp. 13-20.

Intereconomics, March/April 2008
3. Functional flexibility, i.e. the changeability of tasks, of teams, and of the content of work. This is reflected in the mobility of workers within enterprises (internal job turnover). This type of flexibility is reflected by seven questions; here and further see Tangian for specific questions. ${ }^{13}$

4. Wage flexibility, i.e. dependence of salaries and wages on labour market or competitive conditions. This type of flexibility is reflected by seven questions.

5. Externalisation flexibility, i.e. such forms as distance working, teleworking, virtual organisations and selfentrepreneurial activities. This type of flexibility is revealed by six questions.

Precariousness. According to the typology by Keller and Seifert, ${ }^{14}$ the relevant survey questions are classified into three groups:

- income, lower for precarious work than for decent work. To measure the income factor, five questions are used.

- employment stability, the certainty of remaining at work, characterised by four questions on future prospects and past experiences

- employability, capacity to be employed, characterised by four questions on age restrictions for the given work, learning possibilities, health and safety etc.

The fourth section of Table 1, "Partial indices", is reserved for five first-level aggregate flexibility indices (external numerical flexibility, internal numerical flexibility etc.) and three first-level aggregate precariousness indices (income, employment stability and employability). These indices are obtained for every individual.

The fifth section of Table 1, "Aggregate indices", is reserved for second-level aggregate flexibility and precariousness indices.

Every variable (consisting of 23788 answers to a specific question and constituting a table column) was recoded according to the rule: the higher the value, the more flexible (precarious) is work. Then the variables are scaled by two methods which we briefly describe below. ${ }^{15}$

\footnotetext{
${ }^{13}$ A. Tangian: Is flexible work precarious? A study based on the 4th European survey of working conditions 2005, Diskussionspapier 153, Hans Böckler Stiftung, Düsseldorf 2007, http://www.boeckler.de/ pdf/p_wsi_diskp_153_e.pdf.

${ }^{14}$ B. Keller, H. Seifert, op. cit, p. 239.

${ }^{15}$ For details see A. Tangian: Monitoring flexicurity ..., op. cit.; A. Tangian: European flexicurity ..., op. cit.; A. Tangian: Analysis of the third European ..., op. cit.; A. Tangian: Is flexible work precarious? ..., op. cit.
} 
Table 2

Flexibility and Precariousness Indices Constructed by the HBS Method

1a. Flexibility

(in \%, 0-min, 100-max)

\begin{tabular}{|c|c|c|c|c|c|c|}
\hline & $\begin{array}{l}\text { External } \\
\text { numerical } \\
\text { flexibility }\end{array}$ & $\begin{array}{l}\text { Internal } \\
\text { numerical } \\
\text { flexibility }\end{array}$ & $\begin{array}{l}\text { Functional } \\
\text { flexibility }\end{array}$ & flexibility & $\begin{array}{c}\text { Exter- } \\
\text { nalisatior } \\
\text { flexibility }\end{array}$ & \\
\hline Turkey & 71 & 53 & 52 & 22 & 16 & 43 \\
\hline Cyprus & 48 & 55 & 53 & 23 & 12 & 38 \\
\hline Malta & 46 & 52 & 57 & 22 & 12 & 38 \\
\hline Greece & 41 & 53 & 56 & 27 & 11 & 38 \\
\hline Ireland & 33 & 50 & 55 & 25 & 10 & 35 \\
\hline $\begin{array}{l}\text { United } \\
\text { Kingdom }\end{array}$ & 27 & 47 & 55 & 23 & 8 & 32 \\
\hline Finland & 11 & 44 & 59 & 37 & 8 & 32 \\
\hline Poland & 17 & 52 & 55 & 25 & 7 & 31 \\
\hline Denmark & 13 & 41 & 65 & 26 & 10 & 31 \\
\hline Portugal & 20 & 55 & 50 & 25 & 5 & 31 \\
\hline Austria & 19 & 44 & 56 & 28 & 8 & 31 \\
\hline Spain & 22 & 52 & 46 & 27 & 7 & 31 \\
\hline Slovenia & 9 & 45 & 64 & 28 & 7 & 31 \\
\hline Slovakia & 9 & 49 & 54 & 35 & 6 & 31 \\
\hline Luxembourg & 7 & 49 & 56 & 34 & 6 & 30 \\
\hline Romania & 9 & 51 & 54 & 33 & 5 & 30 \\
\hline Bulgaria & 19 & 53 & 52 & 24 & 5 & 30 \\
\hline France & 12 & 47 & 52 & 35 & 6 & 30 \\
\hline Croatia & 12 & 52 & 57 & 23 & 8 & 30 \\
\hline Netherlands & 9 & 43 & 62 & 28 & 9 & 30 \\
\hline $\begin{array}{l}\text { Czech } \\
\text { Republic }\end{array}$ & 11 & 48 & 52 & 31 & 8 & 30 \\
\hline Belgium & 8 & 45 & 58 & 29 & 8 & 30 \\
\hline Germany & 9 & 48 & 54 & 30 & 6 & 29 \\
\hline Estonia & 13 & 44 & 54 & 28 & 7 & 29 \\
\hline Norway & 7 & 46 & 62 & 25 & 8 & 29 \\
\hline Italy & 17 & 47 & 51 & 26 & 6 & 29 \\
\hline Latvia & 10 & 48 & 53 & 28 & 7 & 29 \\
\hline Sweden & 9 & 41 & 60 & 27 & 8 & 29 \\
\hline Switzerland & 7 & 41 & 60 & 26 & 9 & 28 \\
\hline Lithuania & 13 & 48 & 47 & 24 & 6 & 27 \\
\hline Hungary & 11 & 51 & 47 & 23 & 5 & 27 \\
\hline
\end{tabular}

1b. Precariousness



Source: Author's computations derived from: European Foundation: 4th European Working Conditions Survey, European Foundation for the Improvement of Living and Working Conditions, Dublin 2007, http://www.eurofound.europa.eu/publications/htmlfiles/ef0698.htm.

Under normalisation (HBS method), the variable's min and max are reduced to 0 and 1 respectively, and the variable $x=\left(x_{1}, \ldots, x_{23788}\right)^{6}$ is expressed as a percentage of its range:

$y_{i}=\frac{x_{i}-x_{\min }}{x_{\max }-x_{\min }} \cdot 100 \%, \quad i=1, \ldots, 23788$

Under standardisation (OECD method), the mean and standard deviation of a variable are reduced to 0 and 1 respectively, and can be expressed as a percentage thus:

$y_{i}=\frac{x_{i}-\mu}{\sigma} \cdot 100 \%, \quad i=1, \ldots, 23788$

where $\mu=\frac{1}{23788} \sum_{i=1}^{23788} x_{i}$ (mean)

$\sigma=\sqrt{\frac{1}{23788-1} \sum_{i=1}^{23788}\left(x_{i}-\mu\right)^{2}}$

(standard deviation)
The 0 value of $y$ corresponds to the mean of the variable $x$, and the value of $100 \%$ to its "average deviation from the mean".

To obtain first-level aggregate indices, the recoded and scaled variables are summarised within eight groups (five flexibility groups, and three precariousness ones) and the resulting eight column-vectors are either normalised (HBS method) or standardised 
Table 3

Flexibility and Precariousness Indices Constructed by the OECD Method

2a. Flexibility

(in \%, 0-mean, 100-std. dev.)

\begin{tabular}{|c|c|c|c|c|c|c|}
\hline & $\begin{array}{l}\text { External } \\
\text { numerical } \\
\text { flexibility }\end{array}$ & $\begin{array}{l}\text { Internal } \\
\text { numerical } \\
\text { flexibility }\end{array}$ & $\begin{array}{l}\text { Functional } \\
\text { flexibility }\end{array}$ & $\begin{array}{c}\text { Wage } \\
\text { flexibility } n\end{array}$ & $\begin{array}{l}\text { Exter- } \\
\text { nalisation } \\
\text { flexibility }\end{array}$ & $\%$ \\
\hline Turkey & 356 & 121 & -80 & -168 & 279 & 297 \\
\hline Cyprus & 199 & 144 & -41 & -113 & 159 & 192 \\
\hline Greece & 148 & 122 & 18 & -27 & 127 & 192 \\
\hline Malta & 184 & 92 & 51 & -110 & 137 & 189 \\
\hline Ireland & 101 & 31 & 5 & -22 & 58 & 97 \\
\hline Slovakia & -63 & 38 & -36 & 282 & -76 & 43 \\
\hline Finland & -48 & -90 & 86 & 174 & 2 & 28 \\
\hline Slovenia & -63 & -57 & 169 & 106 & -39 & 24 \\
\hline Denmark & -32 & -175 & 222 & -8 & 124 & 22 \\
\hline Poland & -11 & 91 & -2 & -46 & -3 & 10 \\
\hline $\begin{array}{l}\text { United } \\
\text { Kingdom }\end{array}$ & 56 & -18 & -6 & -92 & -11 & -7 \\
\hline Luxembourg & -78 & 2 & 18 & 164 & -84 & -11 \\
\hline Netherlands & -60 & -134 & 141 & 22 & 74 & -15 \\
\hline Croatia & -45 & 70 & 48 & -104 & 30 & -17 \\
\hline Belgium & -70 & -72 & 78 & 51 & 48 & -17 \\
\hline Romania & -59 & 96 & -22 & 56 & -117 & -25 \\
\hline $\begin{array}{l}\text { Czech } \\
\text { Republic }\end{array}$ & -50 & 11 & -85 & 89 & 10 & -28 \\
\hline Spain & 27 & 94 & -186 & -8 & -47 & -29 \\
\hline Norway & -76 & -71 & 114 & -32 & 39 & -31 \\
\hline Portugal & 11 & 140 & -92 & -58 & -138 & -32 \\
\hline France & -42 & -40 & -68 & 164 & -88 & -36 \\
\hline Austria & 2 & -131 & 21 & 15 & -2 & -39 \\
\hline Latvia & -57 & 28 & -63 & -17 & 38 & -49 \\
\hline Estonia & -34 & -88 & -16 & 20 & -20 & -65 \\
\hline Bulgaria & 2 & 110 & -97 & -76 & -168 & -70 \\
\hline Switzerland & -77 & -183 & 118 & -16 & 49 & -79 \\
\hline Sweden & -65 & -191 & 104 & -4 & 29 & -79 \\
\hline Germany & -61 & -11 & -27 & 3 & -91 & -85 \\
\hline Italy & -10 & -27 & -83 & -35 & -115 & -98 \\
\hline Hungary & -50 & 83 & -151 & -105 & -121 & -136 \\
\hline Lithuania & -35 & 15 & -169 & -107 & -81 & -147 \\
\hline
\end{tabular}

2b. Precariousness

\begin{tabular}{|c|c|c|c|c|}
\hline & Income & $\begin{array}{l}\text { Employment } \\
\text { stability }\end{array}$ & Employability & $\%$ \\
\hline Turkey & 133 & 99 & 79 & 182 \\
\hline Latvia & 115 & 128 & -28 & 142 \\
\hline Lithuania & 98 & 131 & -57 & 116 \\
\hline Romania & 95 & 25 & 27 & 103 \\
\hline Poland & 127 & -61 & 29 & 99 \\
\hline Slovakia & 77 & 37 & -36 & 69 \\
\hline Spain & 37 & 107 & -28 & 62 \\
\hline Malta & 101 & -171 & 89 & 56 \\
\hline $\begin{array}{l}\text { United } \\
\text { Kingdom }\end{array}$ & 4 & 142 & -7 & 54 \\
\hline Estonia & 57 & 138 & -149 & 52 \\
\hline Bulgaria & 45 & 43 & -17 & 51 \\
\hline Portugal & 30 & -51 & 122 & 49 \\
\hline Croatia & 68 & -119 & 79 & 41 \\
\hline Greece & -23 & 15 & 160 & 40 \\
\hline Cyprus & 66 & -114 & 68 & 39 \\
\hline Hungary & 98 & -7 & -147 & 35 \\
\hline France & -66 & 206 & 25 & 27 \\
\hline $\begin{array}{l}\text { Czech } \\
\text { Republic }\end{array}$ & 89 & 40 & -211 & 23 \\
\hline Slovenia & 21 & -169 & 92 & -13 \\
\hline Austria & -2 & 20 & -65 & -16 \\
\hline Luxembourg & -117 & 67 & 111 & -41 \\
\hline Denmark & -107 & 27 & 115 & -46 \\
\hline Ireland & -85 & 15 & 44 & -55 \\
\hline Italy & -27 & -6 & -120 & -67 \\
\hline Sweden & -67 & -135 & 113 & -72 \\
\hline Germany & -19 & -9 & -203 & -90 \\
\hline Netherlands & -44 & -80 & -121 & -110 \\
\hline Finland & -148 & -87 & 103 & -129 \\
\hline Belgium & -94 & -159 & 19 & -136 \\
\hline Switzerland & -197 & -20 & -37 & -195 \\
\hline Norway & -264 & -54 & -45 & -271 \\
\hline
\end{tabular}

So urce: Author's computations derived from: European Foundation: 4th European Working Conditions Survey, European Foundation for the Improvement of Living and Working Conditions, Dublin 2007, http://www.eurofound.europa.eu/publications/htmlfiles/ef0698.htm.

(OECD method). According to the OECD, ${ }^{16}$ "most composite indicators rely on equal weighting, i.e. all variables are given the same weight", and we follow this principle. However, standardisation, changing the effective range of variables, implicitly introduces deviation-equalising weights. The second-level aggregate indices of flexibility and of precariousness of work are obtained in a similar manner from two groups of firstlevel aggregate indices (five flexibility and three precariousness indices).

Under normalisation, a first-level aggregated index means the average (coded) response of the individual to the relevant questions. 0 and 100 are attained if all questions are answered in the most extreme way. Nor-

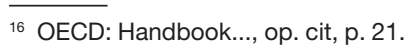
Intereconomics, March/April 2008 malisation is not appropriate for data with outliers - a few large deviations from "typical" values, since the latter become clustered. The EWCS do not contain outliers, because the answer codes are restricted to given values. For instance, income is restricted to 10 deciles. Therefore, normalisation can be applied consistently.

Unlike normalisation, standardisation discriminates well between closely located "typical" values even in the presence of outliers, because it "standardises" the distance between "typical" values. In this way standardisation relativises "good" and "bad" values. For example, the flexibility indicator can have high values and the precariousness indicator low ones. After standardisation, all the values are neither high nor low but medium, and it is impossible to judge wether 
Table 4

Institutional and Factual External Numerical Flexibility for Employees in European Countries/Ranks

\begin{tabular}{|c|c|c|c|c|}
\hline & \multirow{2}{*}{$\begin{array}{c}\begin{array}{c}\text { Institutional } \\
\text { flexibility }\end{array} \\
\text { Strictness of } \\
\text { employment } \\
\text { protection } \\
\text { legislation - the } \\
\text { opposite to the } \\
\text { external numeri- } \\
\text { cal flexibility; the } \\
\text { ranking relates to } \\
\text { flexibility }\end{array}$} & \multicolumn{3}{|c|}{ Factual flexibility } \\
\hline & & $\begin{array}{c}\text { External } \\
\text { numerical } \\
\text { flexibility } \\
\text { (HBS } \\
\text { method) }\end{array}$ & $\begin{array}{c}\text { External } \\
\text { numerical flex- } \\
\text { ibility (OECD } \\
\text { method) }\end{array}$ & $\begin{array}{c}\text { Employ- } \\
\text { ment } \\
\text { with no } \\
\text { contract }\end{array}$ \\
\hline & OECD score $0-5$ & $\begin{array}{l}\text { Normal- } \\
\text { ised \% }\end{array}$ & $\begin{array}{c}\text { Standardised } \\
\%\end{array}$ & $\%$ \\
\hline $\begin{array}{l}\text { United } \\
\text { Kingdom }\end{array}$ & $0.7 / 1$ & $27 / 6$ & $56 / 6$ & $15 / 6$ \\
\hline Ireland & $1.1 / 2$ & $33 / 5$ & $101 / 5$ & $25 / 5$ \\
\hline Switzerland & $1.1 / 2$ & $7 / 31$ & $-77 / 30$ & $4 / 20$ \\
\hline Denmark & $1.4 / 3$ & $13 / 13$ & $-32 / 13$ & $8 / 11$ \\
\hline Hungary & $1.5 / 4$ & $11 / 20$ & $-50 / 19$ & $4 / 18$ \\
\hline Poland & $1.7 / 5$ & $17 / 12$ & $-11 / 12$ & $6 / 13$ \\
\hline $\begin{array}{l}\text { Czech } \\
\text { Republic }\end{array}$ & $1.9 / 6$ & $11 / 19$ & $-50 / 20$ & $2 / 27$ \\
\hline Italy & $1.9 / 6$ & $17 / 11$ & $-10 / 11$ & $9 / 8$ \\
\hline Austria & $1.9 / 6$ & $19 / 9$ & $2 / 9$ & $11 / 7$ \\
\hline Slovakia & $1.9 / 6$ & $9 / 25$ & $-63 / 25$ & $2 / 29$ \\
\hline Finland & $2.0 / 7$ & $11 / 18$ & $-48 / 18$ & $3 / 24$ \\
\hline Netherlands & $2.1 / 8$ & $9 / 23$ & $-60 / 23$ & $2 / 26$ \\
\hline Belgium & $2.2 / 9$ & $8 / 28$ & $-70 / 28$ & $3 / 23$ \\
\hline Germany & $2.2 / 9$ & $9 / 24$ & $-61 / 24$ & $3 / 21$ \\
\hline Sweden & $2.2 / 9$ & $9 / 27$ & $-65 / 27$ & $1 / 30$ \\
\hline Norway & $2.6 / 10$ & $7 / 29$ & $-76 / 29$ & $3 / 22$ \\
\hline Greece & $2.8 / 11$ & $41 / 4$ & $148 / 4$ & $32 / 4$ \\
\hline France & $3.0 / 12$ & $12 / 16$ & $-42 / 16$ & $5 / 16$ \\
\hline Spain & $3.1 / 13$ & $22 / 7$ & $27 / 7$ & $9 / 10$ \\
\hline Portugal & $3.5 / 14$ & $20 / 8$ & $11 / 8$ & $9 / 9$ \\
\hline Turkey & $3.7 / 15$ & $71 / 1$ & $356 / 1$ & $67 / 1$ \\
\hline Estonia & - & $13 / 14$ & $-34 / 14$ & $7 / 12$ \\
\hline Cyprus & - & $48 / 2$ & $199 / 2$ & $42 / 2$ \\
\hline Latvia & - & $10 / 21$ & $-57 / 21$ & $4 / 19$ \\
\hline Lithuania & - & $13 / 15$ & $-35 / 15$ & $5 / 15$ \\
\hline Luxembourg & - & $7 / 30$ & $-78 / 31$ & $1 / 31$ \\
\hline Malta & - & $46 / 3$ & 184 / 3 & $41 / 3$ \\
\hline Slovenia & - & $9 / 26$ & $-63 / 26$ & $2 / 28$ \\
\hline Bulgaria & - & $19 / 10$ & $2 / 10$ & $6 / 14$ \\
\hline Croatia & - & $12 / 17$ & $-45 / 17$ & $2 / 25$ \\
\hline Romania & - & $9 / 22$ & -59 / 22 & $5 / 17$ \\
\hline
\end{tabular}

Source: First column - OECD: Employment Outlook, Paris 2004, p.117 (data for 2003); columns 2-4 - author's computations derived from: European Foundation: 4th European Working Conditions Survey. European Foundation for the Improvement of Living and Working Conditions, Dublin 2007, http://www.eurofound.europa.eu/publications/htmlfiles/ef0698.htm (data for 2005).

flexible work is precarious or not. The only conclusion could be that, for instance, more flexible work is more precarious. Therefore standardisation is adapted for benchmarking rather than for evaluation. Besides, the deviation-equalising weights are non-monotonic func- tions of variables, so that smaller first-level individual indices can result in greater second-level individual indices. ${ }^{17}$

The second-level aggregate indices inherit this property. Those calculated by the HBS method are listed in Table 2 and those by the OECD method in Table 3. The contribution of first-level aggregate indices is shown by the figures in bold, incorporating the equalising weights in the case of the OECD method. The countries are ordered by the aggregate flexibility and precariousness indicated in \% at the right-hand end of the bars. Using the HBS method externalisation flexibility makes the lowest contribution to the aggregate flexibility. This is not the case using the OECD method, which equalises the roles of different factors. Using the HBS method, the aggregate index is the mean of the partial indices. This is not the case using the OECD method, which can be seen in the non-monotonic decrease of the percentage figures in contrast to the monotonically decreasing aggregate index the side-effect of the OECD scaling procedure.

\section{Difference between Institutional and Factual Flexibility of Work}

Table 4 shows indices of the institutional and factual flexibility of work in European countries. The institutional index is the OECD's indicator of strictness of employment protection legislation (EPL). ${ }^{18}$ The factual indices are derived from the EWCS2005 data by either the HBS or the OECD method as described above. Note that Turkey is bottom-ranked with respect to institutional flexibility and top-ranked with respect to factual flexibility. This contradiction is explained as follows. The EPL-evaluation is based on institutional arrangements, showing that the Turkish employment protection legislation is the most rigid among the OECD countries. The empirical survey reveals that 302 of the sample of 454 employees work with no contract, meaning that $67 \%$ of all employees are not under labour market regulation and are working in the most flexible way. A similar situation is inherent in some other countries as well. Factual and institutional situations therefore differ dramatically.

\section{Flexibility Increases the Risk of Precarious Employment}

Figures 1 and 2 show the location of European countries on the flexibility-precariousness coordinate plane. No country is located in the bottom right-hand corner of the plot, where high flexibility coexists with

\footnotetext{
${ }^{17}$ For examples cf. A. Tangian: Is flexible work precarious? ..., op. cit, p. 20.

${ }^{18}$ OECD: Employment Outlook, Paris 2004, OECD, p. 117.
} 
Figure 1

Dependence between Aggregated Flexibility and Precariousness Indices Normalised (HBS Methodology) for European Countries

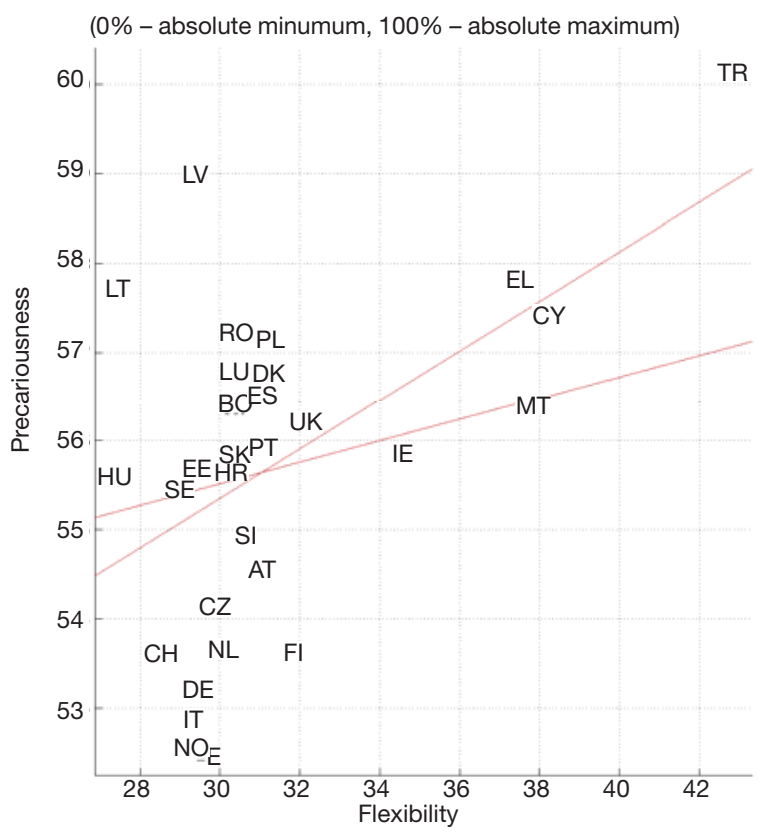

Regression on 31 European Countries: PREC $=47.03+0.28^{\star}$ FLEX $R^{2}=0.2594 F=10.1593 P_{F}=0.0034$

Regression on 23788 individuals: PREC $=51.89+0.12^{*}$ FLEX $R^{2}=0.0120 \mathrm{~F}=287.7543 \mathrm{P}_{\mathrm{F}}=0.0000$

Source: Author's computations derived from: European Foundation: 4th European Working Conditions Survey. European Foundation for the Improvement of Living and Working Conditions, Dublin 2007, http://www.eurofound.europa.eu/publications/htmlfiles/ef0698.htm.

low precariousness. This main target of the European Commission's flexicurity concept seems to be hardly attainable in practice. The reality is still far from the theoretical considerations.

The regression line in Figure 1 computed by the HBS method for 31 European countries also shows that the precariousness of work grows as flexibility increases. The slope of the regression line is $28 \%$ (the first regression equation below the plot). The negligibly small $P$-value $P_{F}=0.0034$ excludes the null hypothesis that the real slope of the line is zero. The regression line in Figure 2 computed by the OECD method for 31 countries has a slope of $26 \%$, but the countries are located somewhat differently, and the $\mathrm{P}$-value $\mathrm{P}_{\mathrm{F}}=0.1584$.

The second regression line in both plots is fitted to 23788 individuals. It is less steep, having a slope of $12 \%$ and $7 \%$ respectively for the indices computed by the HBS and OECD methods; see the second equation below the plots. However, due to a much larger number of observations than for the countries, the $P$-value $P_{F}=0.0000$ is negligibly small in both cases, Intereconomics, March/April 2008
Figure 2

Dependence between Aggregated Flexibility and Precariousness Indices Normalised (OECD Methodology) for European Countries (0\% - mean, $100 \%$ - standard deviation)



Regression on 31 European Countries: PREC $=0.00+0.26^{\star}$ FLEX $\mathrm{R}^{2}=0.0674 \mathrm{~F}=2.0964 \mathrm{P}_{\mathrm{F}}=0.1584$

Regression on 23788 individuals: PREC $=-0.00+0.07^{\star} \mathrm{FLEX}$ $\mathrm{R}^{2}=0.0044 \mathrm{~F}=105.3471 \mathrm{P}_{\mathrm{F}}=0.0000$

Source: Author's computations derived from: European Foundation: 4th European Working Conditions Survey; European Foundation for the Improvement of Living and Working Conditions, Dublin 2007 http://www.eurofound.europa.eu/publications/htmlfiles/ef0698.htm.

so that the positive correlation between flexibility and precariousness of work is statistically certain under both the HBS and the OECD methods.

The regression analysis thus reveals a positive correlation between aggregate flexibility and aggregate precariousness of work all over Europe. No country fulfils the flexicurity condition of high flexibility and low precariousness.

\section{Negative Impact of Flexible Work on Employability}

A more detailed analysis of the impact of flexibility on precariousness is displayed in Figure 3. The bars depict the regression coefficients for the dependence between first-level aggregate indices. The upper bars are obtained by the HBS method and the lower ones by the OECD method (the two top left-hand bars show the regression coefficients 0.12 and 0.07 from Figures 1 and 2). Figure 3 shows the following:

- External numerical flexibility has a low and often statistically non-significant influence on all precarious- 
Figure 3

Regression Coefficients for the Dependence of Aggregate Indices of Precarious Work on Aggregate Indices of Flexible Work

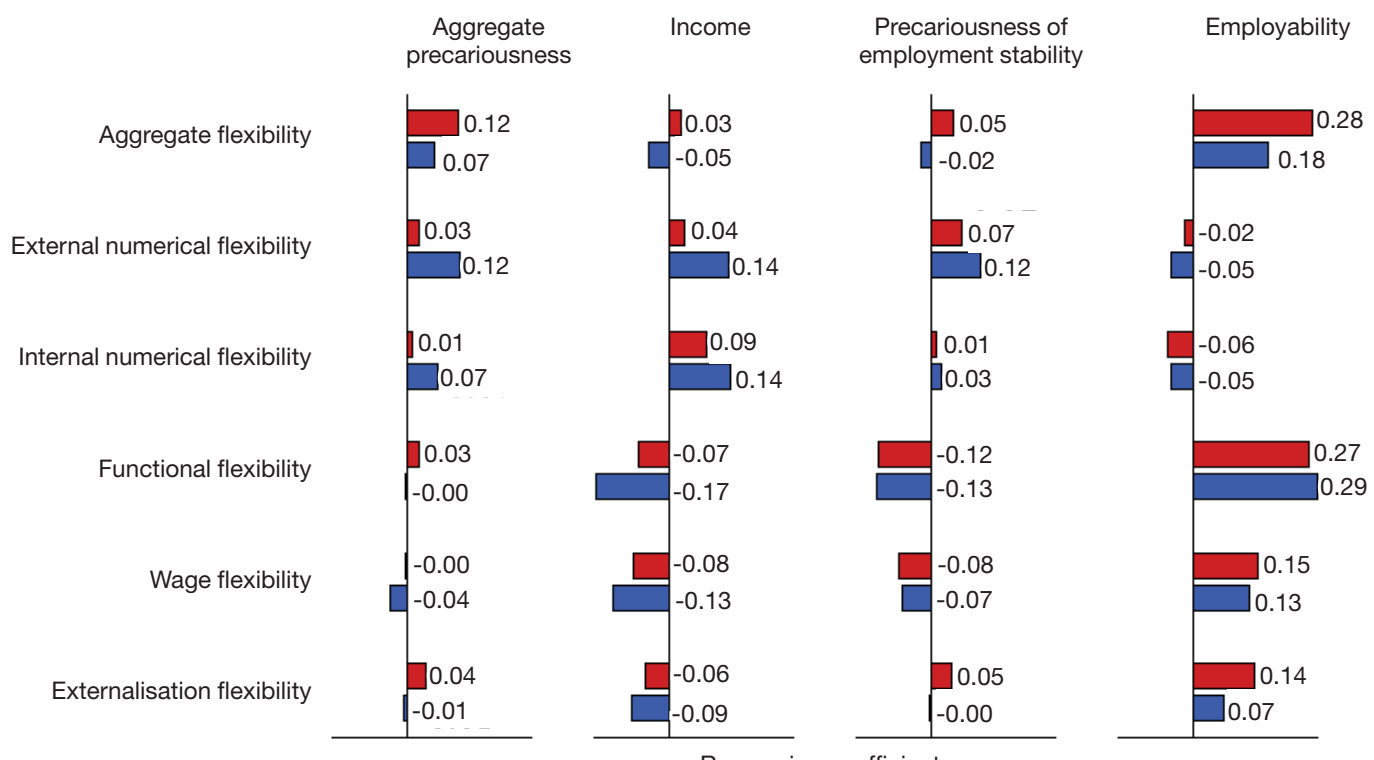

Regression coefficient

Computed for 23788 individuals by the HBS and OECD methods (upper and lower bars, respectively); non-significant deviation of coefficients from zero $(P$-value $>0.05)$ is shown by grey font color.

Source: Author's computations derived from: European Foundation: 4th European Working Conditions Survey; European Foundation for the Improvement of Living and Working Conditions, Dublin 2007, http://www.eurofound.europa.eu/publications/htmlfiles/ef0698.htm.

ness dimensions except for employment stability, in which precariousness increases as flexibility grows.

- Internal numerical flexibility implies a somewhat precarious income but improves employability, which is not surprising.

- Functional flexibility increases the aggregate precariousness, especially the precariousness of employability, but has a positive influence on income and employment stability. The relatively strong cor- relation between flexibility and precariousness of employability can be explained by the reciprocal influence of precariousness of employability on flexible employment. One can imagine that those with low employability are often employed flexibly rather than normally, finding themselves in the vicious circle of flexible-precarious work with few opportunities to escape.

Table 5

Data Structure for Constructing the Hierarchical Composite Indicator of Working Conditions

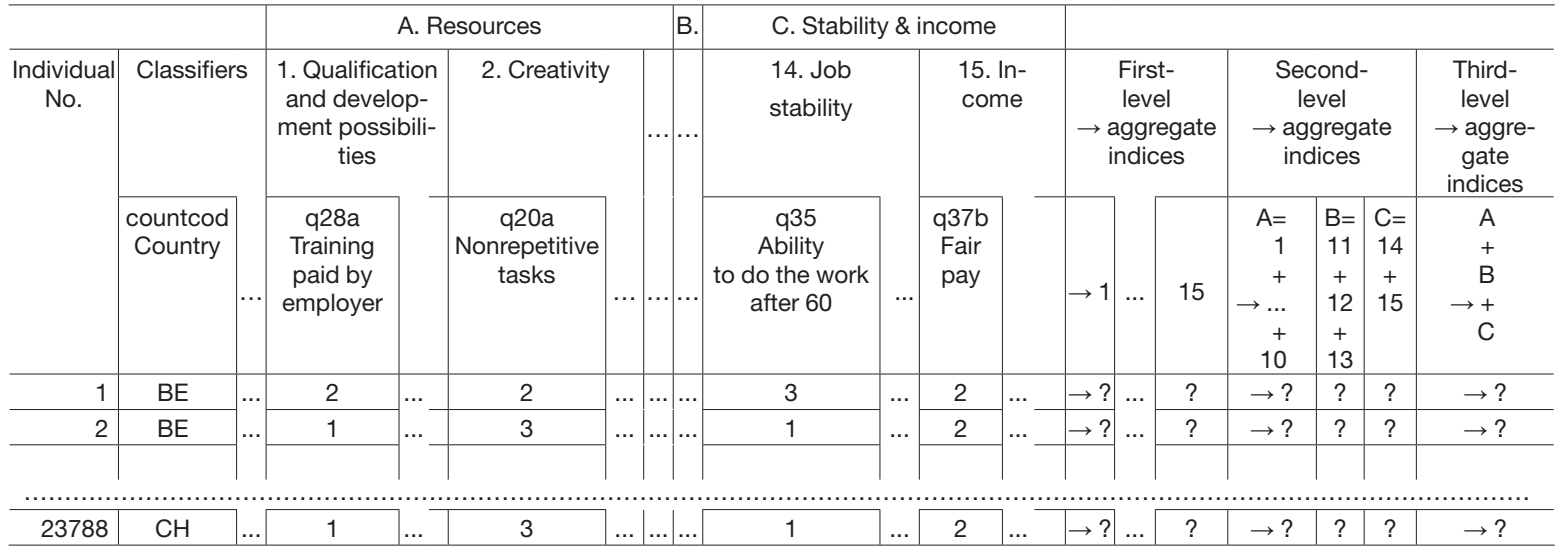

Note: Question marks "?" show the aggregation of composite indicators. 
Table 6

Composition of Aggregate Indices "Total Quality of Work" Computed by the HBS Method"

\begin{tabular}{|c|c|c|c|c|c|c|c|c|c|c|c|c|c|c|c|c|}
\hline & 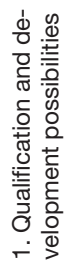 & 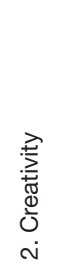 & 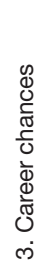 & 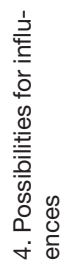 &  & 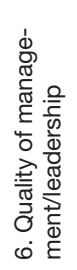 & 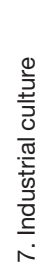 & 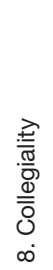 & 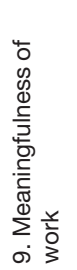 & 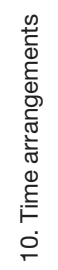 & 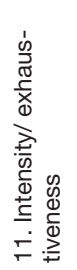 & 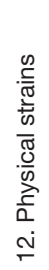 & 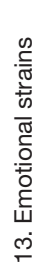 & 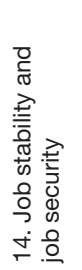 & 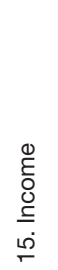 & 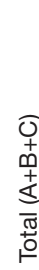 \\
\hline Switzerland & 44 & 77 & 54 & 65 & 58 & 75 & 52 & 75 & 88 & 56 & 68 & 74 & 51 & 75 & 67 & 67 \\
\hline Norway & 38 & 72 & 56 & 64 & 60 & 66 & 55 & 82 & 85 & 54 & 66 & 71 & 48 & 80 & 65 & 66 \\
\hline Denmark & 41 & 68 & 61 & 70 & 54 & 70 & 60 & 84 & 89 & 56 & 65 & 69 & 46 & 80 & 61 & 65 \\
\hline Netherlands & 36 & 70 & 50 & 62 & 55 & 74 & 58 & 74 & 87 & 56 & 71 & 75 & 51 & 75 & 58 & 65 \\
\hline Ireland & 33 & 65 & 57 & 59 & 53 & 70 & 58 & 80 & 82 & 55 & 73 & 75 & 51 & 72 & 61 & 65 \\
\hline United Kingdom & 35 & 59 & 57 & 57 & 55 & 68 & 60 & 79 & 76 & 55 & 69 & 76 & 49 & 76 & 60 & 64 \\
\hline Belgium & 36 & 71 & 51 & 58 & 53 & 69 & 51 & 72 & 83 & 56 & 70 & 73 & 52 & 69 & 65 & 64 \\
\hline Luxembourg & 33 & 68 & 54 & 59 & 49 & 67 & 50 & 70 & 86 & 56 & 72 & 69 & 51 & 66 & 66 & 63 \\
\hline Finland & 44 & 61 & 59 & 65 & 66 & 74 & 54 & 79 & 78 & 56 & 63 & 66 & 49 & 74 & 58 & 63 \\
\hline Sweden & 40 & 77 & 54 & 70 & 54 & 69 & 54 & 82 & 83 & 56 & 64 & 64 & 46 & 76 & 56 & 63 \\
\hline Austria & 38 & 66 & 49 & 56 & 52 & 66 & 55 & 73 & 82 & 55 & 65 & 70 & 50 & 70 & 63 & 62 \\
\hline Germany & 33 & 63 & 48 & 51 & 46 & 59 & 50 & 67 & 78 & 55 & 67 & 73 & 54 & 70 & 60 & 61 \\
\hline Cyprus & 27 & 58 & 53 & 50 & 52 & 74 & 54 & 77 & 88 & 56 & 65 & 67 & 53 & 71 & 57 & 61 \\
\hline Malta & 30 & 74 & 54 & 60 & 45 & 79 & 63 & 80 & 88 & 61 & 65 & 64 & 51 & 70 & 50 & 61 \\
\hline EUROPE - 31 & 33 & 64 & 49 & 56 & 51 & 70 & 54 & 73 & 81 & 55 & 70 & 68 & 52 & 66 & 55 & 61 \\
\hline Spain & 21 & 54 & 48 & 51 & 42 & 66 & 45 & 69 & 78 & 54 & 74 & 69 & 54 & 66 & 60 & 60 \\
\hline Croatia & 36 & 62 & 49 & 63 & 45 & 69 & 59 & 75 & 80 & 54 & 81 & 64 & 47 & 62 & 54 & 60 \\
\hline Bulgaria & 29 & 58 & 42 & 44 & 50 & 82 & 58 & 70 & 84 & 55 & 81 & 66 & 58 & 57 & 50 & 60 \\
\hline Latvia & 34 & 66 & 43 & 59 & 54 & 75 & 61 & 73 & 82 & 53 & 78 & 61 & 51 & 64 & 45 & 59 \\
\hline Slovakia & 36 & 63 & 44 & 47 & 46 & 69 & 60 & 72 & 78 & 55 & 72 & 68 & 58 & 59 & 50 & 59 \\
\hline France & 26 & 61 & 49 & 57 & 46 & 66 & 40 & 61 & 83 & 54 & 72 & 68 & 52 & 61 & 57 & 59 \\
\hline Italy & 26 & 55 & 45 & 53 & 43 & 62 & 37 & 62 & 79 & 55 & 71 & 71 & 56 & 66 & 52 & 59 \\
\hline Hungary & 29 & 61 & 40 & 50 & 51 & 76 & 55 & 77 & 79 & 57 & 70 & 64 & 62 & 64 & 44 & 59 \\
\hline Portugal & 25 & 59 & 54 & 52 & 45 & 57 & 43 & 68 & 83 & 55 & 73 & 67 & 53 & 61 & 54 & 59 \\
\hline Estonia & 36 & 60 & 41 & 56 & 53 & 73 & 55 & 72 & 77 & 54 & 72 & 63 & 52 & 65 & 48 & 59 \\
\hline Romania & 30 & 66 & 47 & 53 & 55 & 70 & 56 & 71 & 86 & 52 & 67 & 66 & 55 & 64 & 46 & 59 \\
\hline Czech Republic & 31 & 57 & 41 & 50 & 50 & 65 & 56 & 66 & 73 & 56 & 67 & 71 & 57 & 56 & 52 & 58 \\
\hline Slovenia & 36 & 66 & 43 & 52 & 48 & 73 & 64 & 72 & 85 & 55 & 66 & 61 & 49 & 56 & 55 & 58 \\
\hline Poland & 30 & 63 & 43 & 52 & 49 & 66 & 54 & 69 & 84 & 53 & 77 & 63 & 56 & 54 & 47 & 57 \\
\hline Lithuania & 29 & 54 & 43 & 51 & 56 & 82 & 54 & 64 & 72 & 54 & 75 & 64 & 49 & 55 & 44 & 56 \\
\hline Greece & 28 & 55 & 46 & 47 & 47 & 74 & 53 & 67 & 75 & 55 & 64 & 55 & 47 & 55 & 55 & 55 \\
\hline Turkey & 27 & 58 & 40 & 52 & 44 & 59 & 43 & 57 & 71 & 58 & 60 & 61 & 56 & 48 & 40 & 51 \\
\hline
\end{tabular}

Good > 80; Superior 70-80; Medium 60-70; Inferior 50-60; Bad $<50$.

${ }^{1}$ Indices scaled by the HBS method (0-abs. min, 100-abs. max).

Source: Author's computations derived from: European Foundation: 4th European Working Conditions Survey. European Foundation for the Improvement of Living and Working Conditions, Dublin 2007, http://www.eurofound.europa.eu/publications/htmlfiles/ef0698.htm.

- Wage flexibility has little influence on the aggregate precariousness of work; it decreases employability, but has a certain positive impact on income and employment stability.

- Externalisation flexibility improves income, does not much affect employment stability, and decreases employability.

- The HBS and OECD methods produce similar results. The regression coefficients show that the impact of functional flexibility on precariousness of employability is far stronger than any other impact.

Intereconomics, March/April 2008

\section{Insufficient Qualification Possibilities and Learning Facilities}

To investigate the second crucial point of the Commission's concept of flexicurity, a comprehensive indicator of working conditions based on 126 questions of the Fourth European Working Conditions Survey was constructed in a similar way to the indicators flexibility and precariousness. The data structure for the indicator is shown in Table $5 .^{19}$

Table 6 shows the composition of the aggregate indicator of working conditions constructed using the HBS method (which enables us to evaluate the situa- 
Table 7

Importance of Different Aspects of Working Conditions for General Satisfaction by the HBS Method ${ }^{1}$

\begin{tabular}{|c|c|c|c|c|c|c|c|c|c|c|c|c|c|c|c|}
\hline & 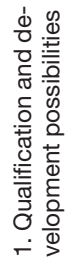 & 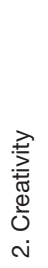 & 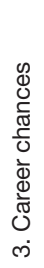 & 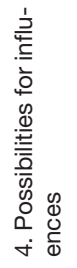 & 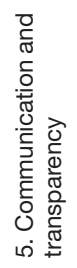 & 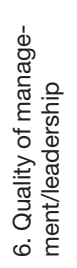 & 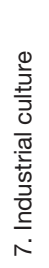 & $\begin{array}{l}\frac{\overrightarrow{ \pm}}{\overline{\mathbb{T}}} \\
\frac{\mathbb{d}}{\bar{O}} \\
0 \\
\infty\end{array}$ &  & 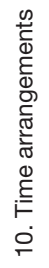 &  & 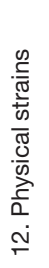 & 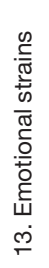 & 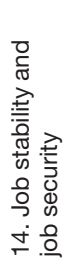 &  \\
\hline EUROPE - 31 & 9 & & 3 & 12 & 13 & 8 & & 4 & 5 & 11 & 7 & 2 & 10 & 1 & 6 \\
\hline Belgium & 6 & & 4 & & & & & 7 & 3 & & 8 & 2 & 5 & 1 & \\
\hline Czech Republic & & & 3 & & & & & 1 & 6 & & 8 & 4 & 7 & 2 & 5 \\
\hline Denmark & & & & 7 & & & & 5 & 1 & & 2 & 3 & & 4 & 6 \\
\hline Germany & & & 6 & & & & & 2 & 3 & & & 4 & 5 & 1 & \\
\hline Estonia & 6 & & 1 & & 9 & & & 4 & 3 & & & 2 & 5 & 8 & 7 \\
\hline Greece & & & 4 & & & & & 3 & & & 5 & 2 & & 1 & 6 \\
\hline Spain & & & 3 & 8 & & & & 5 & 1 & & & 6 & 7 & 2 & 4 \\
\hline France & & & 3 & & & 7 & & 8 & 5 & 9 & 4 & 2 & & 1 & 6 \\
\hline Ireland & & & 2 & & & & & 5 & 3 & & 7 & 4 & 6 & 1 & \\
\hline Italy & & & 2 & & & & & 3 & 5 & & & 4 & & 1 & 6 \\
\hline Cyprus & & 7 & 2 & & & & & 3 & 5 & & 6 & 4 & & 1 & \\
\hline Latvia & & & 7 & 6 & 8 & & & 2 & 4 & & & 1 & & 3 & 5 \\
\hline Lithuania & 5 & & 1 & & & & 8 & 6 & 4 & 9 & & 2 & 10 & 3 & 7 \\
\hline Luxembourg & & 3 & & & & & & 6 & 4 & & 5 & 1 & & 2 & \\
\hline Hungary & & & 3 & & 5 & & & & & 8 & 2 & 6 & 7 & 1 & 4 \\
\hline Malta & & & 2 & & & & & 1 & & & 4 & & 6 & 5 & 3 \\
\hline Netherlands & & 8 & 3 & & & & & 6 & 1 & & 4 & 2 & 7 & 5 & \\
\hline Austria & & & 6 & & & & & 4 & 3 & & 5 & 2 & 7 & 1 & \\
\hline Poland & & 7 & 3 & 8 & & 10 & & 2 & 6 & & 5 & 9 & & 1 & 4 \\
\hline Portugal & & & 1 & 9 & & & 3 & 6 & & 7 & 8 & 5 & & 2 & 4 \\
\hline Slovenia & & & 3 & & & & & 2 & 4 & & 7 & 1 & & 6 & 5 \\
\hline Slovakia & & & 6 & & & 8 & & 1 & 4 & & 7 & 2 & 9 & 3 & 5 \\
\hline Finland & & & 5 & & & & & 2 & 1 & & & 3 & 6 & 4 & \\
\hline Sweden & & & 3 & & & 9 & & 2 & 1 & & 4 & 5 & 8 & 7 & 6 \\
\hline United Kingdom & & & 1 & 7 & & 9 & & & 3 & & 5 & 4 & 8 & 2 & 6 \\
\hline Bulgaria & & & 7 & & & & & 2 & 5 & & 6 & 1 & & 3 & 4 \\
\hline Croatia & & & 2 & & & 8 & & 3 & 6 & & 7 & 1 & & 4 & 5 \\
\hline Romania & & & 6 & & & & & 2 & & & 5 & 1 & & 3 & 4 \\
\hline Turkey & 7 & & 6 & & & 5 & & & 4 & & & 3 & & 1 & 2 \\
\hline Norway & & & 2 & & & 6 & & 1 & 3 & & 5 & 7 & 8 & 4 & \\
\hline Switzerland & & & 2 & & & & 7 & 5 & 4 & & 6 & 3 & & 1 & \\
\hline
\end{tabular}

Negative factors.

Blanks mean that the results were not significant.

1 Importance estimated using the HBS method (1 - most important; 2 - next important, etc.)

Source: Author's computations derived from: European Foundation: 4th European Working Conditions Survey. European Foundation for the Improvement of Living and Working Conditions, Dublin 2007, http://www.eurofound.europa.eu/publications/htmlfiles/ef0698.htm.

tion). In Table 6 the countries are arranged in decreasing order of the top-level aggregate indices displayed at the right-hand side of each row. In the following, the "bad-good" interpretation of the index values is taken from the DGB indicator Gute Arbeit.

Two observations are of particular importance.

- Bad qualification and development possibilities all over Europe. The values in the corresponding first

${ }^{19}$ For details of the construction cf. A. Tangian: Is work in Europe decent? A study based on the 4th European survey of working conditions 2005, Diskussionspapier 157, Hans Böckler Stiftung, Düsseldorf 2007, http://www.boeckler.de/pdf/p_wsi_diskp_157_e.pdf. column of Table 4 are all under 50, meaning a bad evaluation. It is a serious warning signal for the European Employment Strategy oriented towards flexible employment which requires life-long learning.

- Poor career chances all over Europe and modest income. The third column of Table 4 exhibits a bad or inferior evaluation with respect to career chances in all countries except Denmark, which has 61 points (lowest medium level). The income evaluation (column 15) does not surpass the medium threshold. It does not meet the claims for "better jobs" in the European Agenda 2010.

Intereconomics, March/April 2008 
Table 8

Composition of Aggregate Indices "Total Quality of Work" Computed by the HBS Method" by the Type of Contract.

\begin{tabular}{|c|c|c|c|c|c|c|c|c|c|c|c|c|c|c|c|c|}
\hline & 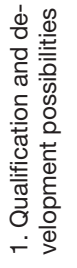 & 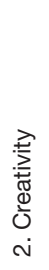 & 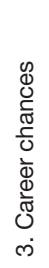 &  &  &  & 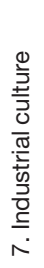 & 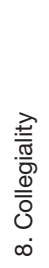 & 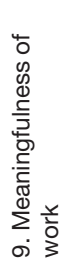 & 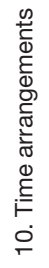 & 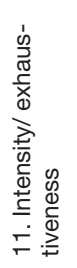 & 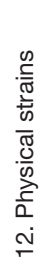 & 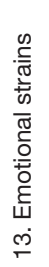 & 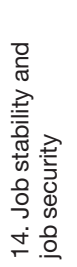 & 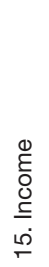 & 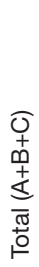 \\
\hline Permanent contract & 34 & 65 & 50 & 57 & 53 & 71 & 54 & 73 & 82 & 55 & 70 & 68 & 51 & 68 & 57 & 62 \\
\hline EUROPE-31 & 33 & 64 & 49 & 56 & 51 & 70 & 54 & 73 & 81 & 55 & 70 & 68 & 52 & 66 & 55 & 61 \\
\hline Fixed-term & 33 & 59 & 48 & 51 & 49 & 69 & 55 & 70 & 80 & 54 & 72 & 68 & 53 & 58 & 50 & 58 \\
\hline No contract & 24 & 57 & 42 & 53 & 41 & 66 & 48 & 69 & 78 & 56 & 69 & 64 & 56 & 62 & 48 & 57 \\
\hline TWA & 25 & 50 & 41 & 45 & 45 & 63 & 55 & 65 & 75 & 53 & 69 & 66 & 55 & 51 & 48 & 55 \\
\hline
\end{tabular}

Good > 80; Superior 70-80; Medium 60-70; Inferior 50-60; $\mathrm{Bad}<50$.

${ }^{1}$ Indices scaled by the HBS method (0-abs. min, 100-abs. max).

Source: Author's computations derived from: European Foundation: 4th European Working Conditions Survey. European Foundation for the Improvement of Living and Working Conditions, Dublin 2007, http://www.eurofound.europa.eu/publications/htmlfiles/ef0698.htm

\section{Importance of Different Aspects of Working Conditions}

The survey question on general satisfaction of working conditions Q36 enables us to investigate the influence of the 15 sub-indicators on job satisfaction by means of stepwise regression. First the independent variable is found which on its own provides the best fit (= the sub-indicator which has the greatest impact on satisfaction with working conditions) and is included in the regression model. Then the next variable is found which improves the fit best when it is included in the model (= the sub-indicator which has the next greatest impact on satisfaction with working conditions), and so on. Table 7, computed using the HBS method (which enables us to evaluate the situation in non-relativised "bad-good" terms) shows the rankings of different factors by country.

What conclusions can be derived from Table 7?

- Most important aspect: job stability. Aspect 14 "Job stability" gets the top rank for Europe as a whole and is also highly ranked in all the individual European countries. Compared to Table 4, some countries with relatively high job stability (Northern countries like Denmark, Finland, Sweden and Norway, some former socialist countries and Malta) do not show the top interest in job stability.

- Income is of relatively low importance. Income is ranked only the 6th important aspect of working conditions for Europe as a whole. The general satisfaction with working conditions in 10 of 31 countries Intereconomics, March/April 2008 does not significantly depend on income, although many Europeans find their income insufficient.

- Negative attitude to qualitative management, training and creativity. The quality of management, and qualification and development possibilities have a negative, although not strong, impact on the general satisfaction with working conditions all over Europe (although it is often non-significant, for example in Germany). Creativity also tends to be perceived as a disadvantage and possibilities for influence are ranked quite low. At the same time, training is highly desired by $70 \%$ of those questioned in the direct German inquiry. ${ }^{20} \mathrm{~A}$ similar response is cited by European Commission. ${ }^{21}$ This means that there is a difference between the rational understanding shown in answers to explicit questions and the unconscious reaction revealed in our indirect analysis. It seems that Europeans are stressed by managerial attention, learning, and the necessity to show initiative, rather than enjoying them. A latent resistance to learning can be the cause of its low efficiency and, consequently, of the low motivation of employers to invest in training, resulting in the poor training possibilities demonstrated in Table 6.

\section{Working Conditions of Atypically Employed}

Table 8 depicts the indices of working conditions computed using HBS method by the type of contract. Those with permanent contracts have the best conditions and others have inferior working conditions

20 DGB, op. cit, p. 24.

${ }^{21}$ European Foundation, op. cit, p. 8. 
which are even worse than the European average. It shows that the Commission's claim of "more and better jobs through flexibility and security" finds no confirmation in reality.

\section{Reform Proposal: Flexinsurance and Workplace Tax}

As can be seen from the empirical studies, the Commission's recommendations for flexicurity are hardly compatible with the actual situation, implying difficulties in policy implementation. A possible solution could be flexinsurance together with elements of the basic minimum income model and a workplace tax.

Flexinsurance assumes that the employer's contribution to social security should be proportional to the flexibility of the contract. ${ }^{22}$ Progressive charges to constrain dismissals are already used in the US unemployment insurance based on experience rating. ${ }^{23}$ The experience rating is the frequency of dismissals in the enterprise and determines the employer's contributions to unemployment insurance: the more frequent the dismissals, the higher the contributions. It is analogous to motor insurance the price of which is influenced by the frequency of accidents. The US practice has two important properties: it operates on the financially fair risk-compensation basis and it constrains the general freedom of the employer to dismiss. The shortcoming of the US experience rating is that the risk of becoming unemployed is linked to dismissals only and pays no regard to the duration and other particularities of the work contract.

Another example of bridging legislation with taxation/insurance is the Austrian Severance Act 2002 (Abfertigungsrecht), which is recognised as good practice both by the European Commission ${ }^{24}$ and the OECD. ${ }^{25}$ The severance payment is accumulated throughout the whole career of an employee in special severance accounts which are accessible upon dismissals or retirement. Employers make obligatory contributions to these accounts of $1.53 \%$ of salaries paid and are no longer charged with severance payments in the case of dismissals. Since dismiss-

\footnotetext{
${ }^{22}$ A. Tangian: European flexicurity ..., op. cit.; A. Tangian: Analysis of the third European ..., op. cit.

${ }^{23}$ A. Graser: Sozialrechtlicher Kündigungsschutz, in: Zeitschrift für Rechtspolitik (ZRP), September 2002, pp. 391-393.

${ }^{24}$ European Commission: Green Paper: Modernising labour ..., op. cit.

${ }^{25}$ OECD: Employment Outlook, Paris 2006, OECD.
}

als were relatively easy in Austria, severance pay has been the major constraint. After the reform, dismissals became a quite formal procedure and employers obtained the freedom to make quick labour force adjustments for the flat $1.53 \%$ "flexibilisation tax".

From the employees' viewpoint, the Abfertigungsrecht is a kind of dismissal insurance. The European Commission ${ }^{26}$ argues that its advantage is that a benevolent change of job does not mean losing the severance entitlement tied to a long tenure. The weakness of the Abfertigungsrecht is that it is case-independent and does not constrain dismissals. The interests of employers are little affected by dismissals because they are seldom charged with severance payments in addition to the obligatory social contributions.

Compared to these prototype practices, flexinsurance has the following advantages:

- Financial fairness. The higher risk of atypical employees' becoming unemployed is compensated for fairly, depending on each individual contract, and contributions to social security correspond to the expectation of unemployment benefits.

- Reasonable employment flexibility. Social security contributions conditioned by the type of contract affect employers' labour costs. Flexinsurance thereby encourages employers to hire employees on more favourable conditions, but does not rigidly restrict labour market flexibility.

- Legislative advantages. Flexinsurance is a flexible instrument for "regulating labour market deregulation". Adjusting the employers' contributions needs no new legislation but just administrative decisions. It is similar to regular changes in the payments to statutory health insurance.

- Social justice. Providing the advantages from flexibilisation to employers free of charge does not appear socially just against the background of increasing inequality. Therefore, flexinsurance is also a policy measure conforming to the principle of social justice. The importance of social feelings is also emphasised in Common Principles: ${ }^{27}$ "Active labour market policies, too, have a positive effect on the feeling of security among workers".

The basic minimum income assumes a flat-rate income paid by the state to all residents, regardless of

\footnotetext{
${ }^{26}$ European Commission: Green Paper: Modernising labour ..., op. cit.

27 European Commission: Towards Common Principles ..., op. cit., p. 14.
} Intereconomics, March/April 2008 
their earnings and property status. ${ }^{28}$ Examples of this model appear in some social security branches, such as childcare allowances or old-age provisions. For instance, Kindergeld in Germany is paid to all parents. Several basic minimum options apply to retirement in Switzerland ${ }^{29}$ and legislation on solidarity pensions is currently underway in Chile. ${ }^{30}$ In a sense, the concept of a basic minimum income is incorporated into the minimum wage. ${ }^{31}$ The additional budget expenditure incurred by the basic minimum income can be covered by:

\section{- flexinsurance}

- higher taxation of high earners (to cover the flat-rate income)

- funds released from reducing the number of civil servants currently working in social security (since the system becomes simpler).

The workplace tax is intended to be imposed on the employers who offer bad working conditions. Similarly to the green tax in environmental protection, which encourages enterprises to consider the natural environment, the workplace tax should stimulate enterprises to consider the working environment. Indexing working conditions can be regarded as measuring the "social pollution" and used to determine the tax amount. A fraction of the tax can be paid directly to the employee as a bonus for bad working conditions. However, the greater part of it should be paid to the state to keep the situation under statutory control.

The workplace tax is particularly topical for atypical employees who, as has been shown, have worse working conditions. If "more and better jobs" are to be attained "through flexibility" then their quality should be controlled and secured.

Additionally, the regulation of atypical employment can also learn from an analogy to the regulation of immigrants, who are "less integrated" into the mainstream that nationals. For instance, there can be quo-

${ }^{28}$ K. Polanyi: The Great Transformation, Boston 1944, Beacon Press 2001.

${ }^{29}$ M. W. Brombacher-Steiner: Die Zweite Säule der Altersvorsorge in der Schweiz, in: Friedrich-Ebert-Stiftung (ed.): Rentenpolitik in Europa. Welches Modell wird zur Leitidee von Reformen, Bonn 2000, pp. 93-102.

30 Chile Presidential Advisory Council: El Derecho a Una Vida Digna en la Vejez: Hacia un Contrato Social con la Previsión en Chile: Resumen Ejecutivo (The Right to a Dignified Old Age: Towards a Welfare Social Contract in Chile: Executive Summary), Santiago 2006, http:// www.consejoreformaprevisional.cl/view/informe.asp.

${ }^{31}$ T. Schulten, R. Bispink, C. Schäfer (eds.): Minimum Wages in Europe, Brussels 2006, ETUI-REHS.

Intereconomics, March/April 2008 tas for atypical contracts (like immigration quotas), employers can be required to justify their necessity (like the obligation to employ own nationals first), issuing a permanent contract after a number of successive temporary contracts (like the permanent residence permit after a few years of temporary residence) etc. These measures are aimed at reasonably constraining employment flexibility without excluding it in the case of its real necessity.

The last factor - but not the least - in preserving the European welfare state is action to constrain the European financial markets. In fact, foreign investments actually mean the export of jobs from Europe to other countries. Employers are given a legal instrument for exerting pressure on European governments: "If you do not relax employment protection according to our requirements, we shall move jobs abroad". Having liberalised financial markets, European governments have paved the way to loss of control over labour markets. Since the way out is generally through the same door as the way in, financial markets must be constrained to some extent in order to restore control - if social priorities are to be respected.

\section{Conclusions}

- Composite indices of flexibility and precariousness of work have been constructed by two methodologies. Both families of indices show that the institutional regulation of employment does not necessarily imply the desired factual effect.

- The analysis of the interaction of the flexibility and precariousness indices shows that the more flexible employment, the more precarious it is. Employment flexibility has the most negative effect on employability.

- This implies serious arguments against the recent suggestions of the European Commission. A shift from job security towards employment security within the flexicurity strategy cannot be implemented consistently. Our study provides empirical evidence that a high employability can hardly be attained under flexible employment. Moreover, Europe is not well-prepared for the life-long learning which should back up employment security under flexibilisation.

- A possible policy instrument for implementing flexicurity might be flexinsurance and a workplace tax together with some other social and economic measures. 